\title{
Colonoscopy quality assurance in Ontario: Systematic review and clinical practice guideline
}

\author{
Jill Tinmouth MD PhD ${ }^{1}$, Erin B Kennedy $\mathrm{MHSc}^{2}$, David Baron $\mathrm{MD}^{3}$, Mae Burke RN ${ }^{4}$, \\ Stanley Feinberg $\mathrm{MD}^{3}$, Michael Gould MD${ }^{5}$, Nancy Baxter MD PhD ${ }^{4}$, Nancy Lewis $\mathrm{PhD}^{5}$
}

\begin{abstract}
J Tinmouth, EB Kennedy, D Baron, et al. Colonoscopy quality assurance in Ontario: Systematic review and clinical practice guideline. Can J Gastroenterol Hepatol 2014;28(5):251-274.
\end{abstract}

Colonoscopy is fundamental to the diagnosis and management of digestive diseases and plays a key role in colorectal cancer (CRC) screening and diagnosis. Therefore, it is important to ensure that colonoscopy is of high quality. The present guidance document updates the evidence and recommendations in Cancer Care Ontario's 2007 Colonoscopy Standards, and was conducted under the aegis of the Program in Evidence-Based Care. It is intended to support quality improvement for colonoscopies for all indications, including follow-up to a positive fecal occult blood test, screening for individuals who have a family history of CRC and those at average risk, investigation for symptomatic patients, and surveillance of those with a history of adenomatous polyps or CRC. A systematic review was performed to evaluate the existing evidence concerning the following three key aspects of colonoscopy: physician endoscopist training and maintenance of competency; institutional quality assurance parameters; and colonoscopy quality indicators and auditable outcomes. Where appropriate, indicators were designated quality indicators (where there was sufficient evidence to recommend a specific target) and auditable outcomes (insufficient evidence to recommend a specific target, but which should be monitored for quality assurance purposes). The guidance document may be used to support colonoscopy quality assurance programs to improve the quality of colonoscopy regardless of indication. Improvements in colonoscopy quality are anticipated to improve important outcomes in digestive diseases, such as reduction of the incidence of and mortality from CRC.

Key Words: Cancer Care Ontario; Colonoscopy; Colorectal cancer screening; Guideline

Colorectal is the most common cancer disease site after the lung and prostate for men, and after the lung and breast for women, with an estimated 4500 new cases of colorectal cancer (CRC) in men and 3600 in women in Ontario in 2011. CRC accounts for $12 \%$ of cancer deaths in Ontario (1).

The risk for developing colon cancer increases with age and is more common in males than in females (2). Several lifestyle variables are also related to the development of CRC, including a convincing increased risk with the consumption of red or processed meat and sugary drinks, and obesity (3). Following guidelines for healthy eating and physical activity can reduce an individual's risk for developing CRC (4).

Colonoscopy is the examination of the large bowel and the distal part of the small bowel with a flexible tube known as an endoscope. It can provide a visual diagnosis and enables the endoscopist to biopsy suspected cancers and/or to remove potential precancerous lesions. Colonoscopy plays an important role in CRC screening (either as a

\section{L'assurance-qualité de la coloscopie en Ontario : une analyse systématique et des lignes directrices}

La coloscopie est essentielle pour diagnostiquer et prendre en charge les maladies digestives, et elle joue un rôle capital pour le dépistage et le diagnostic du cancer colorectal (CCR). Par conséquent, il est important de s'assurer d'une coloscopie de qualité. Les présentes lignes directrices, menées sous les auspices du Programme de soins fondés sur la recherche, mettent à jour les données probantes et les recommandations contenues dans les normes de coloscopie d'Action cancer Ontario de 2007. Elles visent à soutenir l'amélioration de la qualité des coloscopies toutes indications confondues, y compris le suivi d'un test positif de sang occulte dans les selles, le dépistage des personnes qui ont des antécédents familiaux de CCR ou dont le risque est moyen, les examens chez les patients symptomatiques et la surveillance de ceux qui ont des antécédents de polypes adénomateux ou de CCR. Les chercheurs ont procédé à une analyse systématique pour évaluer les données probantes sur trois aspects essentiels de la coloscopie : la formation et le maintien des compétences de l'endoscopiste, les paramètres d'assurance-qualité de l'établissement ainsi que les indicateurs de qualité et les résultats vérifiables de la coloscopie. Dans les cas pertinents, les indicateurs devenaient des indicateurs de qualité (les données étaient suffisantes pour qu'on recommande un objectif précis) et des résultats vérifiables (les données étaient insuffisantes pour qu'on recommande un objectif précis, mais il faudrait les surveiller dans un cadre d'assurance-qualité). Les lignes directrices peuvent soutenir les programmes d'assurance-qualité en vue d'améliorer la qualité de la coloscopie toutes indications confondues. La bonification de la qualité des endoscopies devrait améliorer d'importants résultats cliniques liés aux maladies digestives, tels que la réduction de l'incidence de CCR et de mortalité causée par ce type de cancer.

${ }^{1}$ Sunnybrook Health Sciences Centre, Toronto; ${ }^{2}$ Program in Evidence-based Care, McMaster University/Cancer Care Ontario, Hamilton; ${ }^{3}$ North York General Hospital; ${ }^{4}$ St Michael's Hospital; ${ }^{5}$ Cancer Care Ontario, Toronto, Ontario

Correspondence: Dr Jill Tinmouth, Sunnybrook Health Sciences Centre, 2075 Bayview Avenue, Toronto, Ontario M4N 3M5. Telephone 416-480-5910, fax 416-480-4845 e-mail jill.tinmouth@sunnybrook.ca

Received for publication January 9, 2014. Accepted February 7, 2014 
quality in colonoscopy. The present document provides an update to the 2007 Colonoscopy Standards (7).

In the previous version of the present guideline, the Expert Panel believed that there were insufficient data on which to make recommendations regarding colonoscopy-related bleeding rates, colonoscope withdrawal time (WT), adenoma detection rate (ADR) and cancer miss rates. The present update has not found a marked improvement in the quality of the evidence base for these indicators; however, there is now a greater volume of literature, and new guidance has been published by the European Commission (EC) (8), the Bowel Cancer Screening Program in the United Kingdom (UK) (9) and the Canadian Association of Gastroenterology (CAG) (10). There have also been new studies published on minimum thresholds for development of competency.

Some new indicators have been added since 2007, including polypectomy rate (PR), postcolonoscopy CRC (PCCRC) and adherence to recommended screening intervals. The working group also determined that WT was not an indicator that needed to be tracked or audited for the present version of the guideline. Due to the publication of new evidence, it was possible to specify a target for bleeding rate after polypectomy in the present version of the guideline.

The present guidance document is intended to support quality improvement for colonoscopies for all indications, including follow-up to a positive FOBT, screening for individuals who have a family history of CRC in a first-degree relative, investigation for symptomatic patients, surveillance of those with a history of adenomatous polyps or CRC, and other screening (eg, average-risk screening). The objective of the present guideline is to form the basis of a quality-assurance program for all colonoscopies regardless of indication to improve quality and consistency of colonoscopy in the province and, ultimately, to reduce the incidence of $\mathrm{CRC}$.

The purpose of the present report is to evaluate the existing evidence concerning the following three key aspects of colonoscopy: physician endoscopist training and maintenance of competency; institutional quality assurance parameters; and colonoscopy quality indicators and auditable outcomes.

\section{RESEARCH QUESTIONS}

1. Physician endoscopist training and maintenance of competency

- What primary training is required for physicians performing colonoscopy?

- What are the requirements for maintenance of competency for physicians performing colonoscopy?

\section{Institutional quality assurance parameters}

What are acceptable quality assurance parameters for:

- patient assessment before the procedure;

- infection control, including washing procedures and highpowered washers;

- monitoring during and after the administration of conscious sedation;

- resuscitation capability; and

- acceptable endoscope quality?

3. Colonoscopy quality indicators and auditable outcomes

What are appropriate targets for the following indicators of quality colonoscopy?

- ADR;

- PR;

- cecal intubation rate (CIR);

- colonoscope WT;

- bowel preparation;

- PCCRC;

- bleeding rate after polypectomy; and

- perforation rates.

\section{METHODS}

The evidence-based series guidelines developed by the CCO PEBC use the methods of the Practice Guidelines Development Cycle (11). For the present project, the core methodology used to develop the evidentiary base was the systematic review. Evidence was selected and reviewed by a PEBC methodologist and all other authors. The indicators of interest were chosen by the working group based on the previous version of the guideline (7), with a limited number of additional indicators added based on the opinion of working group members.

The systematic review is a convenient and up-to-date source of the best-available evidence on quality assurance in colonoscopy. The body of evidence in the present review is comprised of observational studies and a review of recommendations published by other guideline developers. These sources form the basis of the recommendations developed by the working group. The systematic review and companion recommendations are intended to promote evidence-based practice in Ontario, Canada.

The PEBC is supported by the Ontario Ministry of Health and Long-Term Care. All work produced by the PEBC is editorially independent of the Ontario Ministry of Health and Long-Term Care.

\section{Literature search strategy}

Websites of international guideline developers, Canadian provincial and national cancer agencies, and CancerViewCanada (www.cancerguidelines.ca) were searched for existing evidence-based practice guidelines or reports published after the final search date of the previous PEBC guideline (July 2006) to May 2012 (for a complete list of databases and associations see Appendix 1).

The electronic databases MEDLINE and Embase were searched for relevant articles from the completion date of the search for the previous PEBC guideline in July 2006 to May 2012. The search strategy was based on the previous guideline, with some modifications to allow for the expanded scope. For the full literature search, see Appendix 2. Reference lists of papers and review articles were scanned for additional citations. The Cochrane Library was searched for topic-specific reviews from 2006 to 2012.

The articles located in the search of electronic databases were eligible for inclusion if they met the following criteria:

- Published full reports and abstract reports of randomized controlled trials or observational studies where any of the items of interest related to the research questions were reported for patients who underwent colonoscopy;

- Reports including physician endoscopists.

The following articles were excluded:

- letters and editorials;

- abstract reports of nonrandomized comparative or non-comparative studies;

- articles published in a language other than English, because of lack of funds for translation;

- studies that were limited to assessment of special populations (eg, high-risk populations);

- studies that assessed flexible sigmoidoscopy or colonoscopy in non-cancer-related disease; and

- studies in which the results for colonoscopy could not be separated from the results for flexible sigmoidoscopy.

Data extraction and quality assessment of included studies Quality assessment for quality assurance guidelines was conducted using the Appraisal of Guidelines for Research and Evaluation 2 (AGREE II) instrument (12), a validated tool to assess the quality and reporting of practice guidelines.

For individual studies, key characteristics, including study location, design, data sources, years of data collection and follow-up, study purpose, colonoscopy indication, and the intervention and comparison under study, were extracted. Outcomes of interest, including all quality indicators listed in the research questions, were extracted. Where 
possible, indirect indicators of colonoscopy quality, such as CIR or procedure volume, were linked to direct indicators of quality such as ADR. ADR and PR vary with the population undergoing the procedures; therefore, studies in which the indication for colonoscopy and variables, such as the age and sex of the population, were not reported were excluded from the analysis for these indicators.

Determination of study quality was based on an assessment of factors such as study design, publication type and relevance to the Ontario population. Data extraction was verified by a project research assistant. All authors reviewed and discussed a draft of the evidence summary. Strengths and weaknesses were evaluated with the aim of characterizing the quality of the evidence base as a whole, without the use of a scoring system or cut-offs, according to the policy of the PEBC.

\section{RESULTS}

Search for existing guidelines

Several guidelines were found in the targeted search of known guideline developers and professional organizations. Three documents were located that focussed on quality assurance in colonoscopy as the primary topic, which overlapped significantly in scope with the purpose and research questions of the present review (8-10). These documents, from Europe (8), Canada (10) and the UK (9), were assessed with AGREE II (Appendix 3), and are briefly described below (13). They are also summarized in Appendix 4 and in relevant sections below, along with other guidelines that did not include quality assurance in colonoscopy as the primary topic but did contain information relevant to our research questions.

EC (8): The EC has issued guidelines for quality assurance in CRC screening and diagnosis for European Union member states, based on a systematic review of the evidence on CRC screening and diagnosis from 2000 to 2008 (8). Because of its high-quality methods and thorough description of the process for developing recommendations, this guideline was given the maximum score on the AGREE II Rigour of Development domain and scored highly on other domains.

Chapter 5, Quality Assurance in Endoscopy in CRC Screening and Diagnosis, provides quality assurance parameters that are relevant to the objectives of the present guideline. Quality indicators, for which there is sufficient evidence to recommend a standard, are provided for quality, safety and patient feedback. In addition, auditable outcomes, which should be monitored, but for which there is no evidence base, are provided. In addition, this guideline states that there should be guidelines in place for components of the procedure such as sedation and colon preparation, policies and supportive processes for other necessary components such as consent, and patient information and selection, and assessment of equipment.

CAG (10): The CAG has created consensus guidelines on safety and quality indicators in endoscopy (10). The methodology for the CAG guidelines appeared to be rigorous and systematic; thus, it rated highly on the AGREE II tool, although the full search strategy was not provided. The guidelines were based on literature obtained through a systematic review from 1990 to 2009, as well as an adaptation of the UK's Global Rating Scale, a tool developed from the patient's perspective to improve quality in endoscopy service delivery, based on indicators developed by the British Society of Gastroenterology. A formal consensus process was used to gauge stakeholder agreement with the resulting 24 statements.

CAG has also produced credentialing guidance, which is consensus based due to a lack of high-quality data that can be used to underpin credentialing standards for endoscopy (14).

National Health Service Bowel Cancer Screening Program (UK) (9): The authors acknowledge that there is no clear evidence to support national standards in some areas of colonoscopy; however, key performance indicators for monitoring have been identified based on consensus opinion and are outlined in this document. The Bowel Cancer Screening Programme uses FOBTs as a primary screen before colonoscopy. Therefore, their indicator targets are for a population that has had a positive screening result on FOBT. Insufficient information was provided to determine whether a systematic review was conducted for this guideline; however, it did provide a comprehensive list of targets and key evidence underpinning each, where available. Lack of evidence of a systematic review led to a lower score on the AGREE II Rigour of Development domain.

\section{Search for existing systematic reviews}

The United States Preventive Services Task Force (USPSTF) released a guideline for CRC screening in 2008 (15), which included a metaanalysis of studies of complications of colonoscopy, including bleeding rates and perforation rates. This systematic review is described in greater detail in the section below that discusses safety indictors in colonoscopy.

\section{Search for primary studies}

Twenty-seven full-text articles were identified in the searches of MEDLINE and Embase that contained comparisons of the outcomes of interest for the performance targets for colonoscopy (see Appendix 5 for the literature search flow diagram). Most were retrospective in design, and there was a lack of consistency among studies regarding comparison groups and outcome measures; therefore, on this basis, the quality of the evidence base, as a whole, was rated as lower quality. These studies are described in greater detail in the sections below.

\section{Training and maintenance of competency for physician endoscopists}

Existing guidance:

Achievement of competency in colonoscopy: In Canada, credentialing individuals for colonoscopy is the responsibility of the endoscopists' local institution or facility (14). To be considered for credentialing, gastroenterologists must complete a formal two-year subspecialty training program, with the option of a third year of subspecialty training before entering full-time practice. Surgical residents usually acquire their endoscopy training in the context of a two-month attachment to a gastroenterology training program. Before being qualified, other physicians must acquire the necessary specific knowledge and technical training in endoscopy over a period of at least six to 12 months (14).

Often, achievement of competency in performing endoscopy is tied to a specific number of completed colonoscopies. For example, the American Society for Gastrointestinal Endoscopy (ASGE) and American College of Gastroenterology set a minimum threshold for assessment of technical competency of 140 supervised colonoscopies, and the Gastroenterological Society of Australia requires 100 training colonoscopies completed without assistance required. In addition, the ASGE and Gastroenterological Society of Australia recommend at least 30 supervised, unassisted snare polypectomies as a threshold for competence as the minimum experience required for proficiency in removal of large polyps and, in particular, sessile polyps from high-risk locations. Although these thresholds are defined, in practice they have been shown to be inadequate for most trainees to achieve competence. Rather, objective criteria of technical competency, such as the CIR, should be used as criteria when granting privileges to physicians for endoscopic procedures (16). Thus, the CAG recommends that competent colonoscopists achieve a CIR of $85 \%$ to $90 \%$ for all colonoscopies and $95 \%$ for screening colonoscopies in healthy adults.

Training is typically conducted through a preceptor who is a recognized authority, and assessments should occur at various levels of training (17). In addition to proficiency in the technical aspects of colonoscopy, proficiency in cognitive aspects of the procedure is essential, including knowledge of appropriate indications and contraindications for colonoscopy, and application of appropriate screening and surveillance intervals.

In Australia, certification of training in colonoscopy is dependent on an assessment of the CIR in intact colons after the completion of minimum training volumes (18). According to the ASGE, when minimum training volumes have been completed, competency is assessed by the training program director, and direct observation of 
the applicant performing endoscopic procedures by an impartial credentialed endoscopist is preferred. According to the United States (US) Joint Commission on the Accreditation of Healthcare Organizations, credentialing is the first step in the process that leads to privileging (19).

The Joint Advisory Group on Endoscopy in the UK has a two-step process for certification. For provisional certification, trainees must have high scores on direct observation of procedural skills and, for full certification, high scores on direct observation of polypectomy skills, low complication rates and sedation rates below the mean recommended dosage. A minimum number of completed procedures (200 for provisional and 300 for full certification) are recommended to gain experience with all common pathology and unusual anatomy.

Maintenance of competence in colonoscopy: The College of Physicians and Surgeons of Ontario outlines expectations for those who have changed or plan to change their scope of practice to include colonoscopy (20). Essentially, these physicians and surgeons are responsible for undergoing an individualized training, supervision and assessment process to be qualified. The features of an acceptable minimum training program include:

- training must be completed within two years of commencement of the program;

- more than one supervisor should be involved in the training;

- a minimum of 100 upper endoscopies performed under high-level supervision (learner is not the Most Responsible Physician;

- a minimum of 200 colonoscopies under high-level supervision;

- a College of Physicians and Surgeons of Ontario (CPSO) interim assessment (including chart review and observation of technique) following completion of the above requirements to allow for progress to practice under moderate supervision (learner is the Most Responsible Physician, but scopes are always performed with a supervisor immediately available);

- a minimum of 100 upper endoscopies under moderate supervision;

- a minimum of 100 colonoscopies under moderate supervision;

- during the period of moderate supervision, the learner will keep track of all indicators as outlined in Section II; and

- a final CPSO assessment (including chart review and observation of technique) for review by the Quality Assurance Committee for consideration of approval of the change of scope of practice.

According to the ASGE, there is good evidence that proficiency in endoscopic procedures is dependent on continued practice and performance of adequate numbers of procedures. Annual colonoscopy volume of $<100$ procedures is associated with a CIR $<90 \%$. Although the evidence for precise volume thresholds is lacking (19), the ASGE recommends that each institution develop and maintain guidelines for granting and renewing privileges, including annual threshold numbers. A physician who is requesting privileges to perform colonoscopy after having been away from practice for a period of time (eg, five years) would be treated in a similar manner as a newly trained physician who is seeking initial privileges, and would undergo proctoring before the granting of privileges (19).

Other recommendations found in various guidance documents for maintenance of competence:

- The Joint Advisory Group on Endoscopy recommends that endoscopists perform at least 300 endoscopies per year;

- EC recommends that each endoscopist participating in a CRC screening program should perform at least 300 procedures per year to ensure sufficient sample size to assess competence. A higher volume is desirable;

- A single study by Ontario investigators also recommends performance of at least 300 colonoscopies per year, based on the EC recommendation (21);

- The National Health Service's Bowel Cancer Screening Programme in the UK recommends performance of more than 150 screening colonoscopies (defined as those following a positive
FOBT) in addition to non-screening colonoscopies per year to maintain competence;

- The Australian National Bowel Cancer Screening Program recommends 250 colonoscopy procedures per proceduralist every five years.

The previous PEBC guideline recommended the performance of 200 colonoscopies per year as a threshold for maintenance of competence. Seventy-six percent of endoscopists performed $>200$ colonoscopies per fiscal year in Ontario in 2008 to 2010 (22), although the CIR in this group did meet recommended guidelines ( $\geq 95 \%)$.

Primary studies:

Study characteristics (Table 1): The systematic review identified three studies that assessed the number of procedures that needed to be performed by surgical or gastroenterology (GI) trainees during a formal period of training to achieve competency in endoscopy. One of these studies was conducted in Korea (23), and two were performed in the US $(24,25)$. One study was a retrospective analysis (25), and the others were prospective $(23,24)$. Most studies included all patients that would normally undergo colonoscopy under routine circumstances. They used a variety of measures to determine competency in endoscopy, such as threshold values for CIR, PR and WT. No primary studies were found that assessed competency among practicing, nontrainee endoscopists.

Study outcomes (Table 2): As mentioned, it has been suggested that a trainee $\log$ at least 140 colonoscopies to establish a minimal level of competence, but findings have shown that is unlikely that a trainee with this level of experience will be able to perform colonoscopy in accordance with benchmarks for quality (16). One study found that first-year GI fellows reached a CIR of $94 \%$ when they had completed 200 colonoscopies and 98\% when they had completed 250 (23). Another study found that it takes an average of 275 procedures to achieve competence in colonoscopy using scores on the Mayo Colonoscopy Skills Assessment Tool, CIRs of $85 \%$ and intubation times $<16$ min as minimal competency criteria (24). Research by Spier et al (25) suggests that 500 colonoscopies are likely required to ensure reliable independent completion rates $(\geq 90 \%)$. In this study, all fellows achieved a reliable independent completion rate of $90 \%$ after 500 colonoscopies, whereas no fellow reached $90 \%$ after 140 colonoscopies.

\section{Institutional guidelines}

The previous version of the present guideline endorsed several recommendations from the CPSO's guidance document for Independent Health Facilities (26), which included recommendations for monitoring and resuscitation during sedation, and infection control. For this version, several new guidelines and reports were found that informed institution-level recommendations (Table 3), including newer guidance from the CPSO. Relevant recommendations from these documents are outlined below. No single primary studies related to institutional standards were found in the search of electronic databases.

Preprocedure assessment: Items to consider in a preprocedure assessment include patient demographics and history, including previous GI procedures. Certain elements of patient history may require precautions before a colonoscopy is performed, and any treatment decisions based on history should be documented. The Quality Assurance Task Group of the National CRC Roundtable (27) recommends documenting the following before the procedure:

- informed consent that conveys risks of the procedure and of false negatives;

- management plan for anticoagulation; and

- management plan for patients with implantable defibrillators and pacemakers.

For meaningful analysis of prevalence rates, age and sex should also be collected.

An Australian guideline for surveillance colonoscopy (28) also includes bowel preparation in the preprocedure assessment, using the following quality indicators: 
TABLE 1

Characteristics of studies related to training and competency

\begin{tabular}{|c|c|c|c|c|c|c|c|c|c|}
\hline $\begin{array}{l}\text { Author, year } \\
\text { (reference) }\end{array}$ & Location & $\begin{array}{l}\text { Study } \\
\text { design }\end{array}$ & Trainees & Data collection & Purpose & $\begin{array}{l}\text { Reason for } \\
\text { colonoscopy }\end{array}$ & Follow-up & $\begin{array}{c}\text { Procedures, } \\
\mathbf{n}\end{array}$ & Outcomes \\
\hline $\begin{array}{l}\text { Lee et al, } \\
2008 \text { (23) }\end{array}$ & Korea & $P$ & $\begin{array}{l}24 \text { first-year GI } \\
\text { fellows }\end{array}$ & $\begin{array}{l}\text { June } 2006- \\
\text { January } 2007\end{array}$ & $\begin{array}{l}\text { Identify measures of compe- } \\
\text { tence, determine adequate } \\
\text { level of training }\end{array}$ & $\begin{array}{l}\text { Screening and } \\
\text { diagnostic }\end{array}$ & None & 4351 & CIR, PR \\
\hline $\begin{array}{l}\text { Sedlack, } 2011 \\
\quad(24)\end{array}$ & $\begin{array}{l}\text { Minnesota, } \\
\text { USA }\end{array}$ & $P$ & $41 \mathrm{GI}$ fellows & $\begin{array}{l}\text { July } 2007- \\
\text { June } 2010\end{array}$ & $\begin{array}{l}\text { Define average learning } \\
\text { curves and minimum stan- } \\
\text { dards for colonoscopy }\end{array}$ & $\begin{array}{l}\text { Routine } \\
\text { outpatient } \\
\text { procedures; } \\
\text { excluded: } \\
\text { therapeutic or } \\
\text { complex } \\
\text { procedures }\end{array}$ & None & 4103 & $\begin{array}{l}\text { CIR, number } \\
\text { of proce- } \\
\text { dures } \\
\text { required to } \\
\text { achieve } \\
\text { competency }\end{array}$ \\
\hline $\begin{array}{l}\text { Spier et al, } \\
2010 \text { (25) }\end{array}$ & $\begin{array}{l}\text { Wisconsin, } \\
\text { USA }\end{array}$ & $\mathrm{R}$ & $\begin{array}{l}21 \text { surgical resi- } \\
\text { dents after } \\
\text { 2-month } \\
\text { endoscopy } \\
\text { rotation }\end{array}$ & $\begin{array}{l}\text { Survey } \\
\text { completed } \\
\text { shortly after } \\
\text { endoscopy } \\
\text { rotations in } \\
\text { July 2004- } \\
\text { June } 2007\end{array}$ & $\begin{array}{l}\text { Assess number of colonos- } \\
\text { copies performed and CIR } \\
\text { for surgical residents during } \\
\text { 2-month rotation and their } \\
\text { perceptions of training }\end{array}$ & Not stated & None & $\begin{array}{c}80 \pm 35 \text { per } \\
\text { resident }\end{array}$ & $\begin{array}{l}\text { CIR, PR, } \\
\text { perceptions } \\
\text { of training, } \\
\text { and compe- } \\
\text { tency after } \\
\text { endoscopy } \\
\text { rotation }\end{array}$ \\
\hline
\end{tabular}

CIR Cecal intubation rate; GI Gastroenterology; P Prospective; PR Polypectomy rate; R Retrospective

TABLE 2

Study outcomes, training and competency

\begin{tabular}{|c|c|c|c|c|c|c|c|c|}
\hline $\begin{array}{l}\text { Author, year } \\
\text { (reference) }\end{array}$ & Trainees & Indication & Procedures, n & CIR, \% & ADR, \% & PR, \% & $\begin{array}{l}\text { WT (no polyp- } \\
\text { ectomy) (min) }\end{array}$ & Notes \\
\hline $\begin{array}{l}\text { Lee et al, } 2008 \\
\quad(23)\end{array}$ & $\begin{array}{l}24 \text { first-year GI } \\
\text { fellows }\end{array}$ & $\begin{array}{l}\text { Screening signs } \\
\text { and symptoms, } \\
\text { family history, } \\
\text { surveillance, } \\
\text { other }\end{array}$ & 4351 & $\begin{array}{l}\text { CIR in }<20 \text { min: } 72 \text { at } \\
50 \text { procedures; } 83 \text { at } 100 ; \\
91 \text { at } 150 ; 94 \text { at } 200 ; 98 \text { at } \\
250 ; 99 \text { after } 250\end{array}$ & $\begin{array}{l}\text { Not } \\
\text { reported }\end{array}$ & 21.8 & Not reported & \\
\hline $\begin{array}{l}\text { Sedlack, } 2011 \\
\quad(24)\end{array}$ & $41 \mathrm{GI}$ fellows & $\begin{array}{l}\text { Routine proce- } \\
\text { dures }\end{array}$ & 4103 & $\begin{array}{l}51 \text { after } 50 \text { procedures; } \\
76 \text { after } 150 ; 85 \text { after } 275 \\
90 \text { after } 400\end{array}$ & $\begin{array}{l}\text { Not } \\
\text { reported }\end{array}$ & Not reported & Not reported & $\begin{array}{l}\text { On average, } \\
275 \text { procedures } \\
\text { recommended } \\
\text { to achieve } \\
\text { competency }\end{array}$ \\
\hline $\begin{array}{l}\text { Spier et al, } \\
2010(25)\end{array}$ & $\begin{array}{l}21 \text { surgical } \\
\text { residents after } \\
\text { 2-month } \\
\text { endoscopy } \\
\text { rotation }\end{array}$ & Not stated & $\begin{array}{l}80 \pm 35 \\
\text { colonoscopies } \\
\text { each (range } \\
40-160 \text { ) }\end{array}$ & Mean: 47 (range 9-78) & $\begin{array}{l}\text { Not } \\
\text { reported }\end{array}$ & Not reported & Not reported & \\
\hline
\end{tabular}

ADR Adenoma detection rate; CIR Cecal intubation rate; GI Gastroenterology; PR Polypectomy rate; WT Withdrawal time

- $100 \%$ of patients receive bowel preparation education;

- $100 \%$ documentation of the type and quality of bowel preparation; and

- $<10 \%$ of patients require a repeat colonoscopy examination due to poor bowel preparation.

EC guidance (8) also addresses the preprocedure assessment, and recommends the collection of the following variables because they can be associated with more adverse events, longer duration and incomplete examinations:

- use of anticoagulants (eg, warfarin);

- anatomy (female sex);

- age of patient;

- previous abdominal surgery;

- body mass index;

- diverticular disease;

- American Society of Anesthesiologists (ASA) classification of patient status and information that may influence type and level of sedation (for those procedures where sedation may be used); and

- presence of risk factors for endocarditis.
Infection control: If endoscopes and accessories are not properly processed, patients can be exposed to contaminants from previous patients, potentially spreading pathogens and causing illness. In the previous version of the present guideline, the CPSO (26) standards regarding infection control were cited, and endorsed by the Expert Panel. The following infection control precautions remain relevant:

- Gastrointestinal endoscopes come into contact with mucous membranes and are considered to be semicritical items. The minimum standard of practice for reprocessing is high-level disinfection.

- Accessories (eg, reusable biopsy forceps) that penetrate mucosal barriers are classified as critical items and must be sterilized between each patient use. Accessories labelled as either single-use or disposable should not be reprocessed.

- Endoscopes have been implicated in the transmission of disease when appropriate cleaning, disinfection, or sterilization procedures were not used. Of particular significance is the need to thoroughly clean equipment manually before any manual or automatic disinfection or sterilization process.

Newer CPSO guidance requires functionally separate areas for reprocessing, scope cabinet and dirty areas in endoscopy/colonoscopy premises (20). 
TABLE 3

Guidance documents that addressed aspects of institutional standards for performance of colonoscopy

\begin{tabular}{|c|c|c|}
\hline Author, year (reference) & Title & Brief description \\
\hline $\begin{array}{l}\text { American Society for } \\
\text { Gastrointestinal Endoscopy, } \\
2009 \text { (34) }\end{array}$ & Automated endoscope reprocessors & $\begin{array}{l}\text { Technology status evaluation report on automated endoscope } \\
\text { reprocessors }\end{array}$ \\
\hline
\end{tabular}

Beilenhoff et al, 2008 (33)

ESGE-ESGENA Guideline: Cleaning and disinfection in gastrointestinal endoscopy

Guidance from the European Society of Gastroenterology (ESGE) and the European Society of Gastroenterology and Endoscopy Nurses and Associates (ESGENA) on cleaning and disinfection in gastrointestinal endoscopy

Cancer Council Australia, 2011 Clinical Practice Guidelines for Surveillance (28) Colonoscopy

Guidance for surveillance colonoscopy in adenoma follow-up, following curative resection of colorectal cancer, and for cancer surveillance in inflammatory bowel disease

Canadian Association of Gastroenterology, 2012 (10)

Canadian Association of Gastroenterology consensus guidelines on safety and quality indicators in endoscopy

Guidance states that quality and safety standards should also address endoscope reprocessing, conscious sedation, monitoring protocols and resuscitation equipment. Reporting systems and databases are also recommended to facilitate quality improvement

CPSO (no publication date provided) (71)

Expectations of physicians who have changed or plan to change their scope of practice to include endo-colonoscopy

CPSO, 2010 (81)

Out-of-Hospital Premises Standards

CPSO, $2011(20)$

Guide to Applying the Out-of-Hospital Standards in Endoscopy/Colonoscopy Premises

Outlines the CPSO's expectations for change in scope of practice. Outlines a system of performance management that focuses on competence rather than paper credentials

Outlines standards for the provision of medical care/procedures in Ontario out-of-hospital premises

Based on the out-of-hospital core standards, this document outlines standards for out-of-hospital premises where colonoscopy is performed in Ontario, with the goal of helping practitioners plan for and participate in their inspection-assessments

European Commission, 2010 European guidelines for quality assurance in (8)

The Quality Assurance Task Group of the National Colorectal Cancer Roundtable, 2007 (27)

United States Food and Drug Preventing Cross-Contamination in Endoscope Administration, 2009 (32) Processing colorectal cancer screening and diagnosis

Standards are provided for quality, safety, and patient feedback before and during the procedure

Standardized colonoscopy reporting and data system: An outline for a standardized colonoscopy reporting and data system report of the Quality Assurance Task Group of the National Colorectal Cancer Roundtable

Communication that outlines the risks to patients if flexible endoscopes and their accessories are not processed properly, and recommends steps to reduce these risks

CPSO College of Physicians and Surgeons of Ontario

Quality of sedation: Most patients in the North American setting are sedated during colonoscopy, although there is a risk for adverse events, especially in patients with pre-existing conditions (2). Moderate (conscious) sedation allows patients to purposefully respond to verbal commands, and no interventions are needed to maintain a patent airway or spontaneous ventilation; therefore, sedation should be targeted to 'moderate' for most patients (29).

The previous version of the present guideline included a review of various sedation regimens and recommended that all patients be offered sedation unless contraindicated, and maintained that patients need to be aware that they have the right to refuse sedation. The present version of the guideline endorses these recommendations, and did not review the primary literature on specific regimens, but focused rather on sedation quality indicators.

A reference cited in the previous PEBC document stated that a preprocedure history and examination for risk factors should be recorded, including ASA classes, because the risk of cardiopulmonary complications is increased in patients with higher ASA scores. That guidance document recommends a continuous quality-improvement target of $100 \%$ for identification of ASA class and appropriate action (30).

Faigel et al (31) lists quality indicators related specifically to sedation:

- obtaining informed consent;

- specifically addressing the most common complications;

- a directed preprocedure history and directed physical examination before the use of moderate or deep sedation;

- documented risk assessment before sedation; and

- specified sedation plan with level of sedation specified before the procedure as minimal, moderate, deep or general anesthesia.
The National Bowel Cancer Screening Program Quality Working Group in Australia provides specific targets for adverse events associated with sedation (2):

- respiratory depression or airway obstruction requiring unplanned intervention in $<1$ in 100 patients;

- hypoxia, defined as pulse oximetry $>10$ percentage points lower than awake preprocedural baseline for $>60$ s consecutively during or after the procedure in $<1$ in 100 patients;

- hypotension requiring drug or fluid therapy in <1 in 100 patients;

- cardiac arrhythmia requiring intervention in <1 in 1000 patients;

- pulmonary aspiration of gastric contents in $<1$ in 1000 patients;

- the use of reversal agents in $<1$ in 100 patients;

- patient complaint about sedation in <1 in 100 patients;

- abnormal discomfort or pain in $<1$ in 100 patients; and

- procedure-related death within 30 days in $<1$ in 10,000 patients.

Monitoring during and after the administration of conscious sedation: Monitoring during and after sedation was addressed by several documents that were reviewed for the previous version of the present guideline, including the Canadian Society of Gastroenterology Nurses and Associates, CPSO and ASGE. The updated search found CAG and Australian guidelines that addressed this topic.

The CAG guideline (10) calls for regular monitoring of sedation level, with implementation of an evidence-based sedation protocol, as well as regular monitoring of blood pressure, pulse, oxygen saturation, etc, during the procedure. Australian guidance notes that there is controversy around appropriate monitoring of sedation; however, appropriate monitoring of vital signs is advised (28). 
TABLE 4

Quality recommendations found in the review of existing guidelines

\begin{tabular}{|c|c|c|c|c|c|}
\hline \multirow{2}{*}{$\begin{array}{l}\text { Organization, year } \\
\text { (reference) }\end{array}$} & \multicolumn{2}{|c|}{ Cecal intubation rate } & \multicolumn{2}{|c|}{ Recommendations } & \multirow{2}{*}{$\begin{array}{c}\text { WT (without polypectomy } \\
\text { or biopsy) }\end{array}$} \\
\hline & Screening & Symptomatic & ADR & PR & \\
\hline PEBC, 2007 (7) & $\begin{array}{l}\text { 95\% provided ade- } \\
\text { quate preparation } \\
\text { and no structural } \\
\text { abnormalities }\end{array}$ & $\begin{array}{l}\text { No recommen- } \\
\text { dations }\end{array}$ & None & None & No recommendation \\
\hline ASGE/ACG, 2007 (27) & $95 \%$ & $90 \%$ & $\begin{array}{l}\text { Screening patients }>50 \text { years of } \\
\text { age: } 25 \% \text { men } 15 \% \text { women }\end{array}$ & None & $\geq 6 \min$ \\
\hline CAG, 2008 (14) & $95 \%$ & $85 \%-90 \%$ & $\begin{array}{l}\text { Screening in healthy asymptomatic } \\
\text { patients >50 years: } 25 \% \text { men; } \\
15 \% \text { women }\end{array}$ & None & $>7 \min$ \\
\hline $\begin{array}{l}\text { European Commission, } \\
2010 \text { (8) }\end{array}$ & $\begin{array}{l}>90 \% \text { acceptable } \\
>95 \% \text { desirable }\end{array}$ & & None & None & $\begin{array}{l}\text { No WT given, but recom- } \\
\text { mended as an outcome to } \\
\text { be monitored }\end{array}$ \\
\hline $\begin{array}{l}\text { National Bowel Cancer } \\
\text { Screening Program UK, } \\
2011 \text { (9) }\end{array}$ & $\begin{array}{l}90 \% \text { with no } \\
\text { adjustment for poor } \\
\text { bowel preparation } \\
\text { or structural lesions }\end{array}$ & & $\begin{array}{l}\geq 35 \% \text { in context of an FOBT-based } \\
\text { screening program }\end{array}$ & None & $\geq 6 \min$ \\
\hline $\begin{array}{l}\text { National Bowel Cancer } \\
\text { Screening Program } \\
\text { Australia, } 2009(2)\end{array}$ & $95 \%$ & $90 \%$ & $\begin{array}{l}>20 \% \text { in patients }>50 \text { years of age } \\
\text { for initial colonoscopy }\end{array}$ & None & $\geq 6 \min$ \\
\hline
\end{tabular}

ADR Adenoma detection rate; ASGE/ACG American Society for Gastrointestinal Endoscopy/American College of Gastroenterologists; CAG Canadian Association for Gastroenterology; FOBT Fecal occult blood test; PEBC Program in Evidence-Based Care; PR Polypectomy rate; UK United Kingdom; WT Withdrawal time

Resuscitation capability: The EC guidance recommends that there should be properly maintained resuscitation equipment in the endoscopy room and recovery area (8). CAG does not provide any guidance on resuscitation capability, other than to say that it is necessary (10).

Endoscope quality: There were no studies found that specifically addressed endoscope quality; however, some guidance from the US Food and Drug Administration was located regarding maintenance of endoscopes, including administrative and technical aspects (32):

- Establishment of a comprehensive Quality Assurance and Safety Program and procedures for monitoring adherence to the program, including standard operating procedures for preparing endoscopes and quality assurance procedures for reprocessing endoscopes and their accessories.

- Training and retraining staff involved with endoscope care and maintenance and establish a chain of accountability for endoscope processing procedures.

- Adherence to the endoscope manufacturer's operating manual and instructions for use.

Guidance has also been published that supports the use of automatic endoscope reprocessors $(33,34)$.

\section{Indicators of performance quality}

The following section contains the results of the search for guidelines and electronic databases for studies that included agreed-upon measures of quality colonoscopy, including:

- ADR;

- PR;

- CIR;

- colonoscope WT; and

- quality of bowel preparation.

Existing guidelines (Table 4): In addition to the previous PEBC guidance on this topic (7), five guidelines were located in the environmental scan that addressed the quality measures of interest and had been published after the previous PEBC search strategy had been completed $(2,8,9,14,27)$. Most guidance located in the environmental scan provided recommendations for CIR, which is often considered the primary indicator of quality (8). CIRs were in the range of $90 \%$ to $95 \%$, depending on the indication and whether the rate was adjusted for factors such as poor bowel preparation or structural abnormalities. In the
UK, there is one standard (90\%), which refers to unadjusted rates (35). The CAG credentialing guidelines indicate a somewhat lower range of CIR for all colonoscopies of $85 \%$ to $90 \%$ as acceptable.

ADRs in screening populations of $>25 \%$ for men and $>15 \%$ for women were recommended by the ASGE/American College of Gastroenterology (27) and endorsed by CAG (14) and the national screening program in Australia (2); however, these thresholds are only valid for US endoscopists performing screening colonoscopies, and do not apply in countries with different CRC rates or ADRs, or where FOBT is used as a primary screening test (36). A recommended WT of at least 6 min to $7 \mathrm{~min}$ was consistent among guidelines $(2,9,14,27)$. No guidelines were found that included a recommendation for PR.

\section{Literature search results}

Study characteristics (Table 5): Thirteen studies (36-48) met the inclusion criteria of the systematic review for studies that reported quality indicators. Only one of these studies took place in Canada (37), and the rest were conducted in the US (38,39,42-48), Europe $(36,40)$ and Taiwan (41). There was a mix of prospective (37$39,41,43,44,48)$ and retrospective $(36,40,42,45-48)$ studies, and data collection occurred at several different levels, from individual endoscopists, to hospital level, to the level of a national screening program. There were several indications reported for colonoscopy, including signs and symptoms, screening (as primary or secondary screen), family history or surveillance, and the population of interest differed according to study. The number of procedures ranged from 522 (41) to almost 24,000 (44). In some studies, single outcomes of interest, such as ADR (46) or PR (41), were reported, and in the rest of the studies, more than one outcome was reported. The studies that evaluated the correlation of multiple indicators on the same population were considered to be of higher quality and more informative for development of quality indicators. Due to the heterogeneity of comparison and outcome groups, it was not possible to pool outcomes across studies.

Study outcomes (Table 6):

CIR (Table 6): CIR is the most commonly used indicator of colonoscopy quality. It is defined as the passage of the instrument tip proximal to the ileocecal valve so that the entire cecal caput is visible (2). A CIR of $90 \%$ for symptomatic patients and $95 \%$ for patients having a screening colonoscopy are commonly cited benchmarks (35). These rates allow for some adjustment for poor bowel preparation, stricture or severe colitis. The previous PEBC guideline was in agreement with the 
TABLE 5

Characteristics of studies reporting quality indicators cecal intubation rate (CIR), adenoma detection rate (ADR), polypectomy rate (PR) and withdrawal time (WT)

\begin{tabular}{|c|c|c|c|c|c|c|c|c|}
\hline $\begin{array}{l}\text { Author, year (ref- } \\
\text { erence), location }\end{array}$ & Design & Data source & $\begin{array}{c}\text { Data } \\
\text { collection }\end{array}$ & Purpose & $\begin{array}{l}\text { Reason for colonoscopy; } \\
\text { exclusions }\end{array}$ & Follow-up & $\begin{array}{c}\text { Procedures, } \\
\mathbf{n}\end{array}$ & Outcomes \\
\hline $\begin{array}{l}\text { Armstrong et al, } \\
2011(37), \\
\text { Canada }\end{array}$ & $\mathrm{P}$ & $\begin{array}{l}\text { Data uploaded by } \\
\text { individual } \\
\text { endoscopists at } \\
19 \text { centres }\end{array}$ & $\begin{array}{r}\text { Feb 2008- } \\
\text { Jun } 2009\end{array}$ & Point-of-care audit & $\begin{array}{l}\text { Abnormality, screening or } \\
\text { surveillance }\end{array}$ & No & $\begin{array}{l}1279 \\
\text { patients }\end{array}$ & $\begin{array}{l}\text { CIR, WT, } \\
\text { PR }\end{array}$ \\
\hline $\begin{array}{l}\text { Barclay et al, } \\
2008(38) \\
\text { USA }\end{array}$ & $\mathrm{P}$ & $\begin{array}{l}\text { Community-based } \\
\text { practice }\end{array}$ & $\begin{array}{l}\text { Jan 2003- } \\
\text { Mar 2004 } \\
\text { compared } \\
\text { with Apr } \\
\text { 2005- } \\
\text { Apr 2006 }\end{array}$ & $\begin{array}{l}\text { Assess implementation of } \\
\text { time-dependent, segmental } \\
\text { withdrawal protocol }\end{array}$ & $\begin{array}{l}\text { No previous colonoscopy. } \\
\text { Excluded: history of } \\
\text { CRC, FOBT+ }\end{array}$ & No & $\begin{array}{l}2325 \\
\text { patients }\end{array}$ & $\begin{array}{l}\text { ADR by } \\
\text { WT }\end{array}$ \\
\hline $\begin{array}{l}\text { Denis et al, } 2011 \\
\text { (36), } \\
\text { France }\end{array}$ & $\mathrm{R}$ & $\begin{array}{l}\text { Database of an } \\
\text { FOBT-based CRC } \\
\text { screening program }\end{array}$ & 2002-2009 & $\begin{array}{l}\text { Determine the most } \\
\text { appropriate quality } \\
\text { indicator and threshold for } \\
\text { neoplasia yield in FOBT } \\
\text { CRC screening programs }\end{array}$ & $\begin{array}{l}\text { FOBT+ average risk. } \\
\text { Excluded: family } \\
\text { history }\end{array}$ & No & 5852 & ADR, PR \\
\hline $\begin{array}{l}\text { Gellad et al, } \\
2010(39) \\
\text { USA }\end{array}$ & $\mathrm{P}$ & $\begin{array}{l}\text { Interview at } \\
\text { enrollment and } \\
\text { procedural data } \\
\text { collected in central } \\
\text { study database }\end{array}$ & $\begin{array}{r}\text { Feb 1994- } \\
\text { Jan } 1997\end{array}$ & $\begin{array}{l}\text { Evaluate relationship } \\
\text { between WT and } \\
\text { advanced neoplasia at } \\
5 \text { years }\end{array}$ & $\begin{array}{l}\text { Veterans. Excluded: lower } \\
\text { gastrointestinal disease } \\
\text { symptoms, examination } \\
\text { within previous } 10 \text { years }\end{array}$ & 4.8 years & 3121 & $\begin{array}{l}\text { WT and } \\
\text { later } \\
\text { missed } \\
\text { adeno- } \\
\text { mas }\end{array}$ \\
\hline $\begin{array}{l}\text { Goncalves et al, } \\
2011(40) \\
\text { Portugal }\end{array}$ & $\mathrm{R}$ & Tertiary hospital & 2005-2009 & $\begin{array}{l}\text { Measure performance in a } \\
\text { single department }\end{array}$ & First-time screening & No & 1545 & $\begin{array}{l}\text { CIR, bowel } \\
\text { prep }\end{array}$ \\
\hline $\begin{array}{l}\text { Hsieh et al, } \\
2009(41), \\
\text { Taiwan }\end{array}$ & $\mathrm{P}$ & $\begin{array}{l}\text { Patients of a single } \\
\text { endoscopist in one } \\
\text { hospital }\end{array}$ & $\begin{array}{l}\text { Jul } 2006- \\
\text { Dec } 2007\end{array}$ & $\begin{array}{l}\text { Investigate effect of increas- } \\
\text { ing endoscope withdrawal } \\
\text { time to } 6 \text { min on PR of one } \\
\text { endoscopist }\end{array}$ & $\begin{array}{l}\text { Asymptomatic. Excluded: } \\
\text { history of abdominal } \\
\text { surgery, incomplete, } \\
\text { poor preparation }\end{array}$ & No & 532 & PR \\
\hline $\begin{array}{l}\text { Lee et al, } \\
2011(48) \text {, } \\
\text { USA }\end{array}$ & $\mathrm{R}$ and $\mathrm{P}$ & $\begin{array}{l}5 \text { academic tertiary } \\
\text { care medical } \\
\text { centres }\end{array}$ & Not stated & $\begin{array}{l}\text { Determine importance of } \\
\text { withdrawal technique in dif- } \\
\text { ferentiating among endos- } \\
\text { copists with varying ADRs }\end{array}$ & $\begin{array}{l}\text { Not part of a screening } \\
\text { program }\end{array}$ & No & 752 & $\begin{array}{l}\text { ADR, WT, } \\
\text { with- } \\
\text { drawal } \\
\text { technique }\end{array}$ \\
\hline $\begin{array}{l}\text { Millan et al, } \\
2008 \text { (42), } \\
\text { USA }\end{array}$ & $\mathrm{R}$ & $\begin{array}{l}\text { Departmental } \\
\text { colonoscopy } \\
\text { database }\end{array}$ & 1998-2004 & $\begin{array}{l}\text { Examine range of ADRs and } \\
\text { contributing factors }\end{array}$ & $\begin{array}{l}\text { Asymptomatic, history of } \\
\text { rectal bleeding, } \\
\text { surveillance }\end{array}$ & No & 16,335 & $\begin{array}{l}\text { CIR, ADR, } \\
\text { proce- } \\
\text { dure } \\
\text { time, } \\
\text { CRC }\end{array}$ \\
\hline $\begin{array}{l}\text { Overholt et al, } \\
2010 \text { (43), } \\
\text { USA }\end{array}$ & $\mathrm{P}$ & $\begin{array}{l}\text { Data collected for } \\
\text { routine clinical } \\
\text { activity quality } \\
\text { assurance }\end{array}$ & $\begin{array}{l}\text { Spring/ } \\
\text { summer } \\
2007\end{array}$ & $\begin{array}{l}\text { Evaluate the impact of colo- } \\
\text { noscopy WT on detection } \\
\text { of polyps }\end{array}$ & Any indication & No & $\begin{array}{l}15,955 \\
\text { patients }\end{array}$ & $\begin{array}{l}\text { WT (impact } \\
\text { on polyps } \\
\text { found) }\end{array}$ \\
\hline $\begin{array}{l}\text { Sawhney et al, } \\
2008 \text { (44), } \\
\text { USA }\end{array}$ & $\mathrm{P}$ & $\begin{array}{l}\text { Medical centre, } \\
\text { gastroenterology } \\
\text { division }\end{array}$ & $\begin{array}{r}\text { Feb 2006- } \\
\text { Jun } 2007\end{array}$ & $\begin{array}{l}\text { Determine if implementation } \\
\text { of colonoscopy WT of } \\
7+\text { min is associated with } \\
\text { greater polyp detection }\end{array}$ & Not stated & No & 23,910 & $\begin{array}{l}\text { PR by } \\
\text { compli- } \\
\text { ance with } \\
7 \text { min WT }\end{array}$ \\
\hline $\begin{array}{l}\text { Simmons et al, } \\
2006(45) \\
\text { USA }\end{array}$ & $\mathrm{R}$ & $\begin{array}{l}\text { Procedure data from } \\
\text { an institutional } \\
\text { computerized } \\
\text { database located at } \\
\text { an outpatient } \\
\text { endoscopy unit }\end{array}$ & $\begin{array}{r}\text { Jan 2003- } \\
\text { Dec } 2003\end{array}$ & $\begin{array}{l}\text { Derive evidence-based } \\
\text { minimum acceptable WTs }\end{array}$ & $\begin{array}{l}\text { 'Routine' cases. Excluded: } \\
\text { complex cases, } \\
\text { incomplete examinations, } \\
\text { suboptimal bowel } \\
\text { preparation, previous } \\
\text { colonic resection, trainee } \\
\text { involvement }\end{array}$ & No & 10,955 & $\begin{array}{l}\text { Polyp yield } \\
\text { by size } \\
\text { by vari- } \\
\text { ous WTs }\end{array}$ \\
\hline $\begin{array}{l}\text { Williams et al, } \\
2011(47) \text {, } \\
\text { USA }\end{array}$ & $\mathrm{R}$ & $\begin{array}{l}\text { Endoscopic database } \\
\text { at Health and } \\
\text { Science University } \\
\text { and Veterans Affairs } \\
\text { Medical Center }\end{array}$ & 2007-2008 & $\begin{array}{l}\text { Compare endoscopists' PRs } \\
\text { and ADRs and to } \\
\text { determine benchmark PRs }\end{array}$ & $\begin{array}{l}\text { Average risk screening. } \\
\text { Excluded: history of } \\
\text { inflammatory bowel } \\
\text { disease, polyposis } \\
\text { syndrome }\end{array}$ & No & 2706 & ADR, PR \\
\hline $\begin{array}{l}\text { Williams et al, } \\
2012(46) \\
\text { USA }\end{array}$ & $\mathrm{R}$ & $\begin{array}{l}\text { Community and } \\
\text { academic } \\
\text { endoscopy units in } \\
\text { the United States }\end{array}$ & 2005-2006 & $\begin{array}{l}\text { Validate the connection } \\
\text { between PR and ADR }\end{array}$ & $\begin{array}{l}\text { Average risk screening. } \\
\text { Excluded: incomplete } \\
\text { examinations }\end{array}$ & No & 14,341 & ADR \\
\hline
\end{tabular}

+ Positive; Apr April; CRC Colorectal cancer; Dec December; Feb February; FOBT Fecal occult blood test; Jan January; Jul July; Jun June; Mar March; P Prospective; R Retrospective 
95\% recommendation for screening colonoscopy, but did not provide a target for those attending for investigation of symptoms. Despite its common use as a quality indicator, recent evidence for the relationship between CIR and incidence of CRC has been mixed; for example, one study found no significant relationship in a population that underwent colonoscopy as a primary screening test (49), while a study of administrative data in Ontario including screening and other colonoscopies did find a significant relationship (50).

The primary studies located in the literature found CIRs ranging from $91 \%$ in the context of first-time screening in a tertiary hospital in Portugal (40) to $99 \%$ in the setting of a community-based practice that was implementing a new withdrawal protocol to improve colonoscopy quality (38). Most sources agree that it is important for each endoscopist to provide photodocumentation of the ileocecal valve and appendiceal orifice to document completion (51). The CAG guideline states that because photodocumentation of cecal intubation is often unavailable, ideally, visualization of landmarks should be documented in writing for every procedure (14).

ADR (Table 6): Adenomas are benign tumours of glandular origin, which may progress over time to malignant adenocarcinoma; therefore, it is important to detect and eliminate adenomas during colonoscopy. ADR is considered to be a robust quality indicator with a significant relationship to CRC incidence (49); however, its use is often limited because pathological analysis is required to determine whether polyps are adenomatous, and this reporting is not available at the time of colonoscopy (52). As mentioned above, prevalence rates of at least one adenoma in colonoscopy screening studies have been consistently $>25 \%$ in men and $>15 \%$ in women $>50$ years of age $(53)$; however, these studies were not always representative of the general population and may not be generalizable to populations in which colonoscopy is not the primary screening test. The EC's systematic review found that rates for the detection of any adenoma or cancer detection ranged in the literature from $14.9 \%$ to $37.5 \%$ (8).

In the previous PEBC guideline, eights studies were identified with ADRs that were extremely variable, ranging from $12 \%$ to $62 \%$; thus, it was determined that a target for ADR could not be specified. This update found an additional seven studies that reported ADRs ranging from $11 \%$ for endoscopists with lower scores on withdrawal technique (48) to approximately $35 \%$ in several studies $(36,38,41,48)$. Where studies reported rates for male and female patients separately, the latter had ADRs that were approximately 10\% lower $(46,47)$.

PR (Table 6): PR, defined as the detection and removal of at least one polyp during colonoscopy, was not included as a quality indicator in the last version of this guideline. Since that time, this indicator has been explored as potentially useful, because unlike ADR, it can be measured at the time of colonoscopy.

The present systematic review found several studies that address the relationship between ADR and PR. One study found a correlation between ADR and PR of $\mathrm{r}=0.88$ (95\% CI $0.78 \%$ to $0.94 \%$ ) in an average-risk asymptomatic population with FOBT-positive test results (36). In another study (46), endoscopists' PRs yielded similar assessments of quality as their ADRs, with a correlation between endoscopists' PRs and ADRs of $r=0.91(P<0.0001)(46)$. This finding led the researchers to propose a benchmark PR of $40 \%$ in men and $30 \%$ in women, because endoscopists who reached these rates almost always reached the ASGE-recommended ADR benchmarks of $25 \%$ and $15 \%$, respectively, and found more advanced lesions (34).

Baxter et al (54) found that median PR for endoscopists over a two-year period was $17.7 \%$ (range $0.0 \%$ to $72.5 \%$ ). Patients undergoing colonoscopy performed by an endoscopist with a PR $\geq 30 \%$ were less likely to develop a proximal PCCRC than if colonoscopy was performed by an endoscopist with a 10\% PR (OR 0.61 [95\% CI $0.42 \%$ to $0.89 \%]$ ). PR was not associated with diagnosis of a distal PCCRC.

In a point-of-care audit, the mean percentage of colonoscopies performed by each endoscopist involving one or more polypectomies was $37.0 \%$ (median $34.0 \%$ ), although $10 \%$ of endoscopists reported polypectomy in $\leq 13.3 \%$ of their colonoscopies (37).
WT (Table 6): Some sources have recommended the monitoring of WT because it has been positively associated with adenoma detection (38), and it can be used as a proxy quality indicator for ADR when the latter indicator cannot be measured reliably. WT is less useful when other, more robust measures of quality are available, such as CIR or ADR (55). WT during colonoscopy when polyps are removed can vary greatly; therefore, monitoring at the endoscopist level should only include patients for whom polypectomy is not required. The previous guideline did not make a recommendation on average colonoscope WT, citing insufficient evidence.

Eleven studies were located that reported WT among fully trained endoscopists ranging from a mean $( \pm$ SD) of $4.2 \pm 1.1 \mathrm{~min}(41)$ to approximately $10 \mathrm{~min}$ (48). In the former study, the group that averaged $4.2 \mathrm{~min}$ had a significantly lower rate of polyp detection compared with a group with an mean WT of $5.7 \pm 1.6$ min $(55.4 \%$ versus 42.4\%; $\mathrm{P}=0.004$ ). Another individual study corroborated the positive relationship between WT and ADR (48). One study found that endoscopists with low ADRs may attain a WT of $\geq 6$ min without demonstrating high-quality withdrawal technique, although this study had several limitations (48). One author proposed inspection time, defined as the period of time that the endoscopist is actively engaged in examining the colonic mucosa for polyps, not including time spent for cleaning or suctioning or during collisions with the bowel wall, as a better indicator than WT(48).

Quality of bowel preparation: The previous PEBC guideline established that proper bowel preparation is essential to quality colonoscopy, because poor preparation can result in a significantly lower polyp detection rate. Guidelines suggest that the percentage of colonoscopies with bowel preparation adequate to detect polyps $>5 \mathrm{~mm}$ should be measured, and inadequate preparation should occur in no more than $10 \%$ of colonoscopies $(27,51)$. Canadian guidelines $(10)$ recommend that a standardized tool, such as the Ottawa Bowel Preparation Scale (OBPS) (56) or the Boston Bowel Preparation scale (57), should be used to assess bowel preparation quality (10).

In a point-of-care practice audit of 1279 patients over 16 months seen by 62 endoscopists at 19 Canadian centres, bowel preparation was excellent in $75.6 \%$ of cases, using an OBPS score of $<5$ as a cut-off (37).

While clinical practice, including methods of bowel preparation, were not the subject of the present review, quality-assurance guidelines found in the review stated that split dosing (ie, dosing at least one-half of the preparation on the day of the colonoscopy) has been established as superior to dosing all the preparation the day before the test $(5,8)$. PCCRC:

Study characteristics (Table 7): Three studies were found that assessed the incidence of PCCRC, ie, new or missed CRC after colonoscopy $(49,50,58)$. Two of the studies included Ontario data $(50,58)$, while the other was conducted in Poland (49). Data sources included administrative data from Ontario databases $(50,58)$ and data collected as part of the national CRC screening program in Poland (49). Two studies excluded higher-risk individuals $(50,58)$. All studies investigated the incidence of CRC in populations that had previously undergone colonoscopy, and some tried to link this indicator with other more established indicators such as CIR $(49,50)$.

Study outcomes (Table 8): Among those who have cancer and who undergo colonoscopy, cancer is missed approximately $4 \%$ to $6 \%$ of the time, with higher miss rates for right-sided (proximal) cancers (14). A study conducted in Ontario found that among those diagnosed with CRC, rates of PCCRC were $3.4 \%$ after three years overall, although the rate of new or missed right-sided CRC was 5.9\% (58). A more recent study conducted in Ontario found that $9 \%$ of patients diagnosed with CRC were considered to have a PCCRC (new or missed cancer diagnosis seven to 36 months after colonoscopy), which is a higher proportion than reported in previous studies (50). In this study, patients with proximal CRC were more likely to have a PCCRC than were patients with distal CRC $(12.4 \%$ versus $6.8 \%, \mathrm{P}<0.0001)$. The authors attribute the higher rate potentially to differing methodology, time period or study population. 
TABLE 6

Study outcomes, cecal intubation rates (CIR), adenoma detection rates (ADR), polypectomy rates (PR) and withdrawal time (WT)

\begin{tabular}{|c|c|c|c|c|c|c|c|c|c|}
\hline $\begin{array}{l}\text { Author, year } \\
\text { (reference) }\end{array}$ & Age, years & $\begin{array}{l}\text { Male } \\
\text { sex, \% }\end{array}$ & Indication & Procedures, $n$ & CIR, \% & ADR, \% & PR, \% & $\begin{array}{l}\text { WT (no polyp } \\
\text { ectomy), min }\end{array}$ & Notes \\
\hline $\begin{array}{l}\text { Armstrong } \\
\text { et al, } 2011 \\
(37)\end{array}$ & $\geq 18$ & & $\begin{array}{l}\text { Investigation } \\
\text { screening } \\
\text { surveillance }\end{array}$ & 1279 & $\begin{array}{r}\text { Mean: } 94.9 \\
\text { Med: } 97.5\end{array}$ & & $\begin{array}{l}\text { Mean: } 37.0 \\
\text { Median: } 34.0\end{array}$ & Median: 6.3 & \\
\hline $\begin{array}{c}\text { Barclay et al, } \\
2008 \text { (38) }\end{array}$ & $\begin{array}{l}\text { Mean BL: } \\
\text { 60.3; mean } \\
\text { PI: } 59.4\end{array}$ & $\begin{array}{l}\text { BL:51; } \\
\text { PI: } 49\end{array}$ & Screening & $\begin{array}{r}\text { BL: 2053; } \\
\text { PI: } 2325\end{array}$ & $\begin{array}{r}\text { BL: 99; } \\
\text { PI: } 99\end{array}$ & $\begin{array}{r}\text { BL: 23.5; } \\
\text { PI: } 34.7\end{array}$ & & $\begin{array}{l}\text { Mean BL: } 6.3 \\
\text { mean PI: } \\
9.8\end{array}$ & \\
\hline $\begin{array}{l}\text { Denis et al, } \\
2011(36) \\
\text { (Haut-Rhin } \\
\text { data) }\end{array}$ & Mean: 62.8 & 53.6 & $\begin{array}{l}\text { FOBT+ family } \\
\text { history }\end{array}$ & 5852 & & $\begin{array}{l}\text { Mean: } 35.6 \\
\text { median: } \\
35.5\end{array}$ & $\begin{array}{l}\text { Mean: } 44.3 ; \\
\text { Median: } 45.2\end{array}$ & & \\
\hline $\begin{array}{c}\text { Gellad et al, } \\
2010(39)\end{array}$ & $\begin{array}{l}\text { Mean: } 62.7 ; \\
\text { range: } \\
50-75\end{array}$ & 95.6 & $\begin{array}{l}\text { Screening } \\
\text { (veterans) }\end{array}$ & 3121 & & & & 13.2 & $\begin{array}{l}\text { No association found } \\
\text { between WT at baseline } \\
\text { colonoscopy and neoplasia } \\
\text { on colonoscopy within } \\
5.5 \text { years }\end{array}$ \\
\hline $\begin{array}{l}\text { Goncalves } \\
\text { et al, } 2011 \\
(40)\end{array}$ & Mean: 60.4 & 38 & $\begin{array}{l}\text { First-time } \\
\text { screening }\end{array}$ & 1545 & 91 & & $\begin{array}{l}33 \text { (men: } 44 \\
\text { versus } \\
\text { women: } 25 \text {, } \\
P=0.0001 \text { ) }\end{array}$ & & \\
\hline $\begin{array}{r}\text { Hsieh et al, } \\
2009(41)\end{array}$ & $\begin{array}{l}\text { Mean B: } 51.8 ; \\
\text { mean A: } \\
53.6\end{array}$ & $\begin{array}{l}\text { B: } 36.1 \\
\text { A: } 42.1\end{array}$ & $\begin{array}{l}\text { Asymptomatic } \\
\text { routine }\end{array}$ & 532 & & $\begin{array}{l}\text { B: } 23.7 \\
\text { A: } 33.9\end{array}$ & $\begin{array}{l}\text { B: } 42.4 ; \\
\text { A: } 55.4\end{array}$ & $\begin{array}{c}\text { B: } 4.2 ; \\
\text { A: } 5.7\end{array}$ & $\begin{array}{l}\text { Single endoscopist, also } \\
\text { included improvement in } \\
\text { withdrawal technique }\end{array}$ \\
\hline $\begin{array}{l}\text { Lee et al, } \\
2011 \text { (48) }\end{array}$ & $\begin{array}{l}\text { Low ADR } \\
\text { group: } 61 \text {; } \\
\text { moderate: } \\
\text { 59; high: } 60\end{array}$ & $\begin{array}{l}\text { Low: } \\
\text { 72.6; } \\
\text { moder- } \\
\text { ate: } \\
69.6 ; \\
\text { high: } \\
52.7\end{array}$ & $\begin{array}{c}\text { Average risk } \\
\text { screening }\end{array}$ & 752 & & $\begin{array}{l}\text { Low: } 11.8 \text {; } \\
\text { moderate: } \\
34.1 \text {; high: } \\
49.0\end{array}$ & & $\begin{array}{l}\text { Low: } 6.3 \text {; } \\
\text { moderate: } \\
\text { 10.2; high: } \\
8.2(P=0.29)\end{array}$ & $\begin{array}{l}\text { Withdrawal technique rather } \\
\text { than WT found to be a pre- } \\
\text { dictor of ADR }\end{array}$ \\
\hline $\begin{array}{r}\text { Millan et al, } \\
2008(42)\end{array}$ & Not stated & $\begin{array}{l}\text { Not } \\
\text { stated }\end{array}$ & $\begin{array}{l}\text { Asymptomatic } \\
\text { screening } \\
\text { history of } \\
\text { rectal } \\
\text { bleeding } \\
\text { surveillance }\end{array}$ & 16,335 & 96.5 & 21 & & $\begin{array}{l}\text { With the } \\
\text { exception of } \\
\text { an outlier, } \\
\text { WT and } \\
\text { ADR } \\
\text { correlation = } \\
0.975 \\
(P=0.0016)\end{array}$ & $\begin{array}{l}\text { CIR fairly uniform, but ADR } \\
\text { varied widely among endos- } \\
\text { copists }\end{array}$ \\
\hline $\begin{array}{l}\text { Overholt et al, } \\
2010(43)\end{array}$ & $\begin{array}{r}\text { Mean } \pm \text { SD: } \\
59.9 \pm 12.8\end{array}$ & 45.5 & $\begin{array}{l}\text { Screening } \\
\text { symptoms } \\
\text { surveillance }\end{array}$ & $\begin{array}{l}15,955 \\
\text { patients }\end{array}$ & & & \multicolumn{3}{|c|}{$\begin{array}{l}\text { Endoscopists with mean WT } \geq 6 \text { were } 1.8 \text { times more likely } \\
\text { to detect } 1 \text { or more polyps and had a significantly higher } \\
\text { rate }(P<0.0001) \text { of polyp detection compared with } \\
\text { endoscopists with mean WT }<6 \text { min }\end{array}$} \\
\hline $\begin{array}{l}\text { Sawhney } \\
\text { et al, } 2008 \\
(44)\end{array}$ & Mean: 56.8 & 46 & $\begin{array}{l}\text { Screening } \\
\text { surveillance } \\
\text { symptoms }\end{array}$ & & & & \multicolumn{3}{|c|}{$\begin{array}{l}\text { When compliance with a } 7 \text { min WT for nontherapeutic } \\
\text { colonoscopies improved from } 65 \% \text { to } 100 \% \text { of } \\
42 \text { endoscopists at a single centre, there was no increase } \\
\text { in polyp detection ratio }(P=0.45)\end{array}$} \\
\hline $\begin{array}{l}\text { Simmons } \\
\text { et al, } 2006 \\
(45)\end{array}$ & Mean: 62.5 & 54.4 & $\begin{array}{l}\text { Routine out- } \\
\text { patient }\end{array}$ & 10,955 & & & \multicolumn{3}{|c|}{$\begin{array}{l}\text { Median PR of } 42.7 \% \text { corresponded to a withdrawal time of } \\
6.7 \text { min, with a correlation between overall PR and mean } \\
\text { endoscopist WT of } 0.76, P<0.0001 \text {. }\end{array}$} \\
\hline $\begin{array}{c}\text { Williams et al, } \\
2011 \text { (47) }\end{array}$ & $\begin{array}{l}\geq 50 \text {; mean: } \\
\quad 59.6\end{array}$ & 71 & $\begin{array}{c}\text { Average-risk } \\
\text { screening }\end{array}$ & 2706 & & $\begin{array}{l}\text { Men: } 29.5 \\
\text { women:12.7 }\end{array}$ & $\begin{array}{l}\text { Men: } 43.5 \text {; } \\
\text { women: } \\
25.8\end{array}$ & & $\begin{array}{l}\text { Suggest a PR of } 40 \% \text { for men } \\
\text { and } 30 \% \text { for women } \\
\text { corresponds to ADRs of } \\
25 \% \text { and } 15 \%\end{array}$ \\
\hline $\begin{array}{l}\text { Williams et al, } \\
2012(46)\end{array}$ & $\begin{array}{l}\geq 50 ; \text { mean } \\
\text { (male): } \\
60.7 ; \\
\text { (female): } \\
61.2\end{array}$ & 49.0 & $\begin{array}{l}\text { Average-risk } \\
\text { screening }\end{array}$ & 14,341 & & \multicolumn{2}{|c|}{$\begin{array}{l}\text { Male: ADR: } 35.4, \text { PR: } \geq 40 ; \\
\text { female: ADR: } 25.7 \text { PR: } \\
\geq 30 . \text { Correlation between } \\
\text { PR and ADR: males = } \\
0.91, P=0.0001 ; \text { females }= \\
0.91, P=0.0001\end{array}$} & & \\
\hline
\end{tabular}

+ Positive; A After; B Before; BL Baseline; FOBT Fecal occult blood test; PI Postintervention

Kaminski et al (49) investigated cancer incidence in the interval between initial screening colonoscopy and subsequent surveillance colonoscopy in the context of a national bowel cancer screening program that uses colonoscopy as the primary screening test. Interval 
TABLE 7

Study characteristics, postcolonoscopy colorectal cancer (PCCRC)

\begin{tabular}{|c|c|c|c|c|c|c|c|c|c|}
\hline $\begin{array}{l}\text { Author, year } \\
\text { (reference) }\end{array}$ & Location & Design & Data source & $\begin{array}{c}\text { Data } \\
\text { collection }\end{array}$ & Purpose & $\begin{array}{l}\text { Reason for colonos- } \\
\text { copy; exclusions }\end{array}$ & Follow-up & $\begin{array}{c}\text { Procedures, } \\
\mathbf{n} \\
\end{array}$ & Outcomes \\
\hline $\begin{array}{c}\text { Baxter et al, } \\
2011(50)\end{array}$ & Canada & $\mathrm{R}$ & $\begin{array}{l}\text { OCR, OHIP, CIHR } \\
\text { Discharge Abstract } \\
\text { Database, } \\
\text { Registered Persons } \\
\text { Database, Ontario } \\
\text { Physicians Human } \\
\text { Resources Data } \\
\text { Centre }\end{array}$ & $\begin{array}{l}\text { CRC diagnosis } \\
\text { between } \\
\text { 2000-2005 }\end{array}$ & $\begin{array}{l}\text { Determine if performance- } \\
\text { based quality indicators } \\
\text { could be identified at the } \\
\text { endoscopist level using } \\
\text { administrative data; } \\
\text { validity of these } \\
\text { indicators for predicting } \\
\text { PCCRC }\end{array}$ & $\begin{array}{l}\text { Excluded: <20 years, } \\
\text { previous diagnosis of } \\
\text { CRC, outside direct } \\
\text { billing area, Crohn } \\
\text { disease, ulcerative } \\
\text { colitis, incomplete } \\
\text { examination, previ- } \\
\text { ous colon resection }\end{array}$ & 36 months & $\begin{array}{l}14,064 \\
\text { patients } \\
\text { with CRC }\end{array}$ & $\begin{array}{l}\text { PR, CIR, } \\
\text { PCCRC }\end{array}$ \\
\hline $\begin{array}{l}\text { Bressler } \\
\text { et al, } 2007 \\
(58)\end{array}$ & Canada & $\mathrm{R}$ & $\begin{array}{l}\text { ClHI, Registered } \\
\text { Persons Database, } \\
\text { Ontario Cancer } \\
\text { Registry }\end{array}$ & $\begin{array}{l}\text { New CRC } \\
\text { from April } \\
\text { 1997-March } \\
2002\end{array}$ & $\begin{array}{l}\text { Evaluate the frequency of } \\
\text { and risk factors for new } \\
\text { and missed CRC by } \\
\text { colonoscopy in a } \\
\text { population-based study }\end{array}$ & $\begin{array}{l}\text { Excluded: ulcerative } \\
\text { colitis, Crohn } \\
\text { disease, <20 years } \\
\text { at diagnosis, had } \\
\text { previous flexible } \\
\text { sigmoidoscopy }\end{array}$ & 36 months & 12,487 & PCCRC \\
\hline $\begin{array}{l}\text { Kaminski } \\
\text { et al, } 2010 \\
\text { (49) }\end{array}$ & Poland & $\mathrm{R}$ & $\begin{array}{l}\text { National CRC } \\
\text { Screening Program } \\
\text { for Poland }\end{array}$ & $\begin{array}{l}\text { October } \\
\text { 2000-2004 }\end{array}$ & $\begin{array}{l}\text { Assess association } \\
\text { between quality } \\
\text { indicators and risk of } \\
\text { interval cancer }\end{array}$ & $\begin{array}{l}\text { National colonoscopy- } \\
\text { based screening } \\
\text { program. Excluded: } \\
\text { poor preparation }\end{array}$ & $\begin{array}{l}188,788 \\
\text { person- } \\
\text { years }\end{array}$ & 45,026 & $\begin{array}{l}\text { PCCRC } \\
\text { by ADR, } \\
\text { CIR }\end{array}$ \\
\hline
\end{tabular}

ADR Adenoma detection rate; CIHI Canadian Institute for Health Information; CIHR Canadian Institutes of Health Research; CIR Cecal intubation rate; CRC Colorectal cancer; OCR Ontario Cancer Registry, OHIP Ontario Health Insurance Plan; PR Polypectomy rate; $R$ Retrospective

TABLE 8

Study outcomes, postcolonoscopy colorectal cancer (PCCRC)

\begin{tabular}{|c|c|c|c|c|c|}
\hline $\begin{array}{l}\text { Author, year } \\
\text { (reference) }\end{array}$ & Age, years & $\begin{array}{c}\text { Male } \\
\text { sex, \% }\end{array}$ & $\begin{array}{l}\text { Colonoscopies } \\
\text { included in } \\
\text { PCCRC }\end{array}$ & Patients, n & PCCRC \\
\hline $\begin{array}{c}\text { Baxter et al, } \\
2011(50)\end{array}$ & $\begin{array}{l}\text { Patients with } \\
\text { CRC: } \\
\text { median } 68 \text {; } \\
\text { patients } \\
\text { with } \\
\text { PCCRC: } \\
\text { median } 71\end{array}$ & $\begin{array}{l}\text { CRC: } \\
\text { 56.6; } \\
\text { PCCRC: } \\
52.7\end{array}$ & $\begin{array}{l}\text { Complete } 7-36 \\
\text { months before } \\
\text { CRC diagnosis }\end{array}$ & $\begin{array}{l}\text { CRC: } 34,312 ; \\
\text { complete colo- } \\
\text { noscopy } \\
\text { within } 36 \\
\text { months of } \\
\text { CRC diagno- } \\
\text { sis: } 14,064 ; \\
\text { PCCRC: } 1260\end{array}$ & $\begin{array}{l}9 \% \text { of those who had a colonoscopy within } 36 \text { momths of CRC diagnosis were } \\
\text { considered to have a new or missed cancer (PCCRC) } \\
\text { Cecal intubation rate of } \geq 85 \% \text { versus }<80 \% \text {, and polypectomy rate of } 25 \% \text { versus } \\
<10 \% \text { both associated with significantly reduced chance of PCCRC }\end{array}$ \\
\hline $\begin{array}{l}\text { Bressler } \\
\text { et al, } 2007 \\
(58)\end{array}$ & Mean: 67.7 & 56 & $\begin{array}{l}\text { Most recent } 6-36 \\
\text { months before } \\
\text { CRC diagnosis }\end{array}$ & $\begin{array}{l}\text { CRC: } 12,487 ; \\
\text { PCCRC: } 430 \\
\text { after } 2 \text { years }\end{array}$ & $\begin{array}{l}430 \text { of } 12,487 \text { patients diagnosed with } C R C \text { had undergone a colonoscopy within } \\
\text { the previous } 2 \text { years (excluding the } 6 \text { months before diagnosis) }=2.4 \% \\
\text { After } 3 \text { years: } 3.4 \% \\
\text { After } 5 \text { years: } 4.6 \%\end{array}$ \\
\hline $\begin{array}{l}\text { Kaminski } \\
\text { et al, } 2010 \\
(49)\end{array}$ & $\begin{array}{l}50-66 \text { (and } \\
40-49 \text { at } \\
\text { increased } \\
\text { risk) }\end{array}$ & 35.7 & Primary screening & 45,026 & $\begin{array}{l}\text { HR for interval cancer* according to adenoma detection rates: } \\
<11.0 \%: 10.94(95 \% \mathrm{Cl} 1.37 \%-87.01 \%) \\
11.0 \%-14.9 \%: 10.75(95 \% \mathrm{Cl} 1.36 \%-85.06 \%) \\
15.0 \%-19.9 \%: 12.50(95 \% \mathrm{Cl} 1.51 \%-103.43 \%) \\
\geq 20.0 \% \text { (reference group) } \\
\mathrm{P}=0.02 \text { for all comparisons; nonsignificant relationship between } \mathrm{CIR} \text { and interval } \\
\text { cancer }(\mathrm{P}=0.50)\end{array}$ \\
\hline
\end{tabular}

*Interval cancer defined as colorectal cancer (CRC) diagnosis between screening colonoscopy and scheduled time of surveillance colonoscopy

cancer was found to have a significant relationship to ADR, with a HR of 12.50 (95\% CI $1.51 \%$ to $103.43 \%$ ) for an ADR of $15.0 \%$ to $19.9 \%$ compared with an ADR of at least 20\%. This study did not find a significant association with CIR and PCCRC. This may have been because this study involved a younger cohort (40 to 66 years of age); reaching the cecum is less of a factor for younger populations because they are at lower risk for proximal cancers.

Bleeding after polypectomy and perforation rates:

Existing guidelines (Table 9): The previous PEBC guideline concluded that there was insufficient evidence to make a recommendation regarding colonoscopy bleeding rate. The working group for this guideline considered that bleeding postpolypectomy was most relevant, and searched for existing guidance on recommended thresholds for postpolypectomy bleeding. Two guidelines were found that recommend a rate of $<1 \%$ after polypectomy $(2,9)$.
The previous PEBC guideline endorsed the US Multi-Society Task Force on CRC's continuous quality-improvement target for perforations of $<1$ per 1000 overall, and $<1$ per 2000 for screening colonoscopies (30). New guidance published since that time includes targets from CAG of $<1$ in 500 in all patients and $<1$ in 1000 in screening patients (14), and the UK (9) and Australian guidance (2) both suggest a quality threshold of $<1$ per 1000 for perforations caused by colonoscopy. The European Union review found that perforation rates were $2 \%$ with and $0.06 \%$ without removal of polyps (8).

Literature search results - indicators of colonoscopy safety:

Study characteristics (Table 10): A systematic review (15) and eight other articles (37,59-65), including a review article (62), contained outcomes of interest related to the safety of colonoscopy. Two studies reported rates of bleeding after polypectomy $(60,64)$ and, in addition, data regarding this indicator were extracted from three additional 
TABLE 9

Safety cut-off found in the review of guidance documents

\begin{tabular}{|c|c|c|}
\hline Organization, year (reference) & Bleeding rate & Perforation rate \\
\hline $\begin{array}{l}\text { Program in Evidence-Based Care, } \\
2007 \text { (53) }\end{array}$ & Insufficient data to make a recommendation & Screening: $\leq 1 / 2000$; overall: $\leq 1 / 1000$ \\
\hline $\begin{array}{l}\text { Canadian Association of } \\
\text { Gastroenterology, } 2008 \text { (14) }\end{array}$ & $\begin{array}{l}\text { Overall risk for postpolypectomy bleeding should be }<1 \% \text {; however, bleeding risk } \\
\text { increases with size of polyp and may exceed } 10 \% \text { for polyps }>2 \mathrm{~cm} \text {, particularly in } \\
\text { the proximal colon }\end{array}$ & $<1 / 500$ all patients, $<1 / 1000$ screening \\
\hline European Commission, 2010 (8) & $\begin{array}{l}\text { From literature review: major postexcision hemorrhage in range of } 0.2 \%-2.7 \% \text {, } \\
\text { depending on size of lesion }\end{array}$ & $2 \%$ with and $0.06 \%$ without excision \\
\hline $\begin{array}{l}\text { National Bowel Cancer Screening } \\
\text { Program United Kingdom, } 2011 \\
\text { (9) }\end{array}$ & $<1 \%$ postpolypectomy & $<1 / 1000$ \\
\hline $\begin{array}{l}\text { National Bowel Cancer Screening } \\
\text { Program Australia, } 2009 \text { (2) }\end{array}$ & $<1 \%$ postpolypectomy & $<1 / 1000$ \\
\hline
\end{tabular}

studies (66-68) that were part of the USPSTF's systematic review (15). Bleeding in the absence of polypectomy was not considered to be an important event; therefore, bleeding rates were only extracted from studies that reported this indicator after polypectomy. Six primary studies $(37,59,61,63-65)$ and the two reviews reported perforation rates $(15,62)$. Two of these studies were conducted in Canada $(37,63)$, and the remainder were conducted in the US $(15,59,64)$, Europe $(60,65)$ and Israel $(61)$. There was a mix of prospective $(37,60,65)$ and retrospective $(59,61,63,64)$ studies. As in the studies of colonoscopy quality indicators, a variety of data sources was used, from physician self-reports $(37,61)$ to large health-information databases $(37,63)$. Indications for colonoscopy varied considerably from one study to the next, and included screening, signs and symptoms, family history and surveillance. The number of procedures ranged from $1126(60)$ to $>1$ million procedures from a Medicaid database (59). Due to the heterogeneity of comparison and outcome groups, it was not possible to pool outcomes across studies.

Study outcomes (Table 11):

Bleeding rates after polypectomy (Table 11): Two studies reported a rate of bleeding after polypectomy of $<1 \%(60,64)$. The study with the higher rate included patients who underwent colonoscopy for reasons other than screening, including signs and symptoms, family history and polyp control $(0.94 \%)(60)$. In a screening population, the postpolypectomy bleeding rate was $0.50 \%$ or one in 200 (64). The USPSTF meta-analysis of 12 studies found that major bleeding from colonoscopy occurred in 12 per 10,000 procedures in asymptomatic patients (15); however, this analysis included studies that did not report whether polypectomy had been performed. The rates ranged from $0.40 \%(67)$ to $0.48 \%$ (66) for three studies from this analysis that did report bleeding only for patients who had polyps removed.

Perforation rates (Table 11): Nine studies located in the present review found perforation rates that were generally $<1$ per 1000 . The USPSTF meta-analysis of 13 studies found that perforations occurred at a rate of 0.56 per 1000 in asymptomatic populations (15).

\section{RECOMMENDATIONS}

The present recommendations are based on the best evidence currently available and are not intended to constitute absolute requirements for individual endoscopists. The recommended targets can be monitored and used to provide feedback to individuals to improve performance on quality indicators when necessary, and to monitor performance at the system level to improve the overall quality of colonoscopy in Ontario. A quality improvement program should document its requirements, monitor performance using established quality indicators, and then institute changes that will lead to demonstrated improvements upon reassessment.

Recommendations from the previous version of the present guideline (7) were used as a starting point and were updated where new evidence justified a modification. The following criteria were used by the guideline development group as a guide to ensure consistency and transparency when specifying target thresholds or values:
1. Evidence that the target is linked to an established important outcome (eg, ADR, PCCRC).

2. Evidence that the target is applicable in the Ontario context.

3. Taking into account the quality of evidence, targets were identified with a preference for values that were in the middle of the range found the literature, to set reasonably attainable targets for Ontario.

Some indicators are dependent on the underlying risk profile of the population. For example, ADR is expected to be higher than average in populations that have been referred for colonoscopy after a positive FOBT or fecal immunochemical test (FIT), or in those with a family history or other risk factors such as previous polyps.

Quality and safety indicators (p.13) for which there were sufficient evidence to recommend a specific target are called quality indicators. Important quality indicators are labelled auditable outcomes where there was insufficient evidence to recommend a specific target, but there was working group agreement that the indicator should be monitored for quality assurance purposes. These labels are consistent with those used in other guidance documents $(8,9)$. As data accumulate, it may be possible to establish targets for these auditable indicators or to make necessary adjustments to targets that are already specified.

\section{TARGET POPULATION}

The present guideline is intended to provide guidance on quality colonoscopy for adult patients undergoing this procedure in Ontario.

\section{INTENDED USERS}

The present guideline is intended for clinicians involved in the delivery of colonoscopy to patients in Ontario and for policy makers and program planners involved in quality assurance at Cancer Care Ontario and in hospitals and clinics. Colonoscopy may be performed for a variety of indications, specifically: follow-up to a positive FOBT, screening for those who have a family history of CRC in a first-degree relative, investigation for symptomatic patients, surveillance of those with a history of adenomatous or serrated polyps, inflammatory bowel disease or CRC, and other screening (eg, average-risk screening).

\section{TRAINING AND MAINTENANCE OF COMPETENCY}

\section{Primary training}

Recommendations:

- To be considered for credentialing, gastroenterologists must complete a formal two-year subspecialty training program, with the option of a third year of subspecialty training, before entering full-time practice.

- Before being qualified, other physicians, including surgical residents, must acquire the necessary specific knowledge and technical training in colonoscopy over a period of at least six months. 
TABLE 10

Study characteristics, indicators of colonoscopy safety

\begin{tabular}{|c|c|c|c|c|c|c|c|c|c|}
\hline $\begin{array}{l}\text { Author, year } \\
\text { (reference) }\end{array}$ & Location & Design & Data source & $\begin{array}{c}\text { Data } \\
\text { collection }\end{array}$ & Purpose & $\begin{array}{c}\text { Reason for } \\
\text { colonoscopy; } \\
\text { exclusions }\end{array}$ & Follow-up & Procedures, $n$ & Outcomes \\
\hline $\begin{array}{l}\text { Armstrong } \\
\text { et al, } 2011 \\
(37)\end{array}$ & Canada & $\mathrm{P}$ & $\begin{array}{l}\text { Data uploaded by } \\
\text { individual } \\
\text { endoscopists at } \\
19 \text { Canadian } \\
\text { centres }\end{array}$ & $\begin{array}{l}\text { February } \\
\text { 2008-June } \\
2009\end{array}$ & Point-of-care audit & $\begin{array}{l}\text { Abnormality, } \\
\text { screening or } \\
\text { surveillance }\end{array}$ & No & 1279 patients & $\mathrm{BR}, \mathrm{PFR}$ \\
\hline $\begin{array}{l}\text { Arora et al, } \\
2009(59)\end{array}$ & USA & $\mathrm{R}$ & $\begin{array}{l}\text { Medicaid database } \\
\text { fee-for-services } \\
\text { claims }\end{array}$ & $\begin{array}{l}\text { January } \\
1995 \text { - } \\
\text { June } 2005\end{array}$ & $\begin{array}{l}\text { Assess risk of } \\
\text { perforation and } \\
\text { associated factors }\end{array}$ & $\begin{array}{l}\text { Screening, } \\
\text { diagnostic or } \\
\text { therapeutic }\end{array}$ & 7 days & $1,350,157$ & PFR \\
\hline $\begin{array}{l}\text { Baudet et al, } \\
2009(60)\end{array}$ & Spain & $\mathrm{P}$ & $\begin{array}{l}5 \text { randomly selected } \\
\text { patients/day in } \\
\text { clinic }\end{array}$ & $\begin{array}{l}\text { January } \\
\text { 2005- } \\
\text { December } \\
2006\end{array}$ & $\begin{array}{l}\text { Determine minor } \\
\text { adverse event rates } \\
\text { in outpatient } \\
\text { colonoscopy }\end{array}$ & $\begin{array}{l}\text { Signs, symptoms, } \\
\text { family history, } \\
\text { polyp control. } \\
\text { Excluded: } \\
\text { abdominal } \\
\text { resection, } \\
\text { pregnant, high } \\
\text { anesthesia risk }\end{array}$ & 30 days & 1126 & $\mathrm{BR}$ \\
\hline $\begin{array}{l}\text { Crispin et al, } \\
2009(65)\end{array}$ & Germany & $\mathrm{P}$ & $\begin{array}{l}\text { Compulsory health } \\
\text { insurance } \\
\text { members }\end{array}$ & 2006 & $\begin{array}{l}\text { Estimate incidence of } \\
\text { acute complications; } \\
\text { identify risk factors }\end{array}$ & $\begin{array}{l}\text { Screening, signs } \\
\text { and symptoms, } \\
\text { adenoma } \\
\text { surveillance, } \\
\text { cancer aftercare }\end{array}$ & No & 236,087 & BR, PFR \\
\hline $\begin{array}{l}\text { Niv et al, } 2011 \\
(61)\end{array}$ & Israel & $\mathrm{R}$ & $\begin{array}{l}\text { Physician self- } \\
\text { reports to Health } \\
\text { Institutes covered } \\
\text { by Israeli insur- } \\
\text { ance company }\end{array}$ & $\begin{array}{l}\text { January } \\
\text { 2000- } \\
\text { December } \\
2006\end{array}$ & $\begin{array}{l}\text { Analyze complications } \\
\text { of colonoscopy }\end{array}$ & $\begin{array}{l}\text { Most procedures } \\
\text { performed for } \\
\text { diagnostic } \\
\text { reasons }\end{array}$ & No & 252,064 & BR, PFR \\
\hline $\begin{array}{l}\text { Panteris et al, } \\
2009(62)\end{array}$ & $\begin{array}{l}\text { Not } \\
\text { reported }\end{array}$ & Review & $\begin{array}{l}\text { Articles in MEDLINE } \\
\text { (15 studies } \\
\text { included to } \\
\text { determine overall } \\
\text { perforation rate) }\end{array}$ & 2000-2008 & $\begin{array}{l}\text { Characterize } \\
\text { incidence of } \\
\text { perforation and } \\
\text { related factors }\end{array}$ & $\begin{array}{l}\text { Screening and } \\
\text { other (high-risk } \\
\text { included) }\end{array}$ & $\begin{array}{l}\text { Not } \\
\text { reported }\end{array}$ & 491,311 & PFR \\
\hline $\begin{array}{l}\text { Rabeneck } \\
\text { et al, } 2008 \\
(63)\end{array}$ & Canada & $\mathrm{R}$ & $\begin{array}{l}\text { Canadian Institute } \\
\text { for Health } \\
\text { Information } \\
\text { Discharge Abstract } \\
\text { Database }\end{array}$ & $\begin{array}{l}\text { April 2002- } \\
\text { March } \\
2003\end{array}$ & $\begin{array}{l}\text { Determine rates of } \\
\text { bleeding, perforation } \\
\text { and death } \\
\text { associated with } \\
\text { outpatient } \\
\text { colonoscopy and } \\
\text { associated factors }\end{array}$ & $\begin{array}{l}\text { Approximate } \\
\text { screening } \\
\text { cohort. } \\
\text { Excluded: } \\
\text { diagnosis of } \\
\text { CRC in previous } \\
5 \text { years }\end{array}$ & 30 days & 97,091 & BR, PFR \\
\hline $\begin{array}{c}\text { Rutter et al, } \\
2012 \text { (64) }\end{array}$ & USA & $\mathrm{R}$ & $\begin{array}{l}\text { Washington Health } \\
\text { Care System }\end{array}$ & 1994-2009 & $\begin{array}{l}\text { Detailed analysis of } \\
\text { risk for usual } \\
\text { screening and } \\
\text { follow-up } \\
\text { colonoscopies }\end{array}$ & $\begin{array}{l}\text { Screening and fol- } \\
\text { low-up after } \\
\text { other screening } \\
\text { test in previous } \\
6 \text { months }\end{array}$ & 30 days & 43,456 & $\mathrm{BR}, \mathrm{PFR}$ \\
\hline $\begin{array}{l}\text { Whitlock et al } \\
2008 \text { (15) }\end{array}$ & USA & SR & $\begin{array}{l}\text { Articles located } \\
\text { through MEDLINE, } \\
\text { Cochrane Library, } \\
\text { expert sugges- } \\
\text { tions, bibliographic } \\
\text { reviews }\end{array}$ & $\begin{array}{l}\text { Current to } \\
\text { January } \\
2008\end{array}$ & $\begin{array}{l}\text { Consider community } \\
\text { performance of } \\
\text { screening } \\
\text { endoscopy, } \\
\text { including harms }\end{array}$ & Screening & $\begin{array}{l}\text { Not } \\
\text { reported }\end{array}$ & $\begin{array}{l}\text { Perforation:173,391 } \\
\text { (13 studies); } \\
\text { bleeding with pol- } \\
\text { ypectomy: } 31,921 \\
\text { (3 studies); overall } \\
\text { bleeding: } 55,461 \\
\text { (12 studies) }\end{array}$ & $\mathrm{BR}, \mathrm{PFR}$ \\
\hline
\end{tabular}

BR Bleeding rate; $P$ Prospective; PFR Perforation rate; $R$ Retrospective; SR Systematic review

Key evidence: The guideline development group endorses the recommendations of the CAG regarding the requirements for credentialing.

\section{Attainment of competency}

Recommendations:

- To be considered competent colonoscopists, trainees should achieve an average independent CIR of at least $85 \%$ for all colonoscopies and are expected to have performed at least 300 colonoscopies during training. The independent CIR should be measured on a subset of colonoscopies performed at the end of training. If 300 colonoscopies are performed during training, it is anticipated that at least 50 polypectomies would have been performed.
- In addition to proficiency in the technical aspects of colonoscopy, proficiency in cognitive aspects of the procedure is essential, including knowledge of appropriate contraindications and indications for colonoscopy, application of appropriate screening and surveillance intervals (17), histological classification of polyps and their significance, and knowledge of how to deal with findings encountered at the time of colonoscopy.

Key evidence: Most sources located in the review state that competent colonoscopists should be able to intubate the cecum in $\geq 90 \%$ of all cases (53). The consensus of the guideline development group was that a slightly lower threshold of at least $85 \%$ for new endoscopists was realistic at the completion of training, with the justification that the 
TABLE 11

Study outcomes, indicators of colonoscopy safety

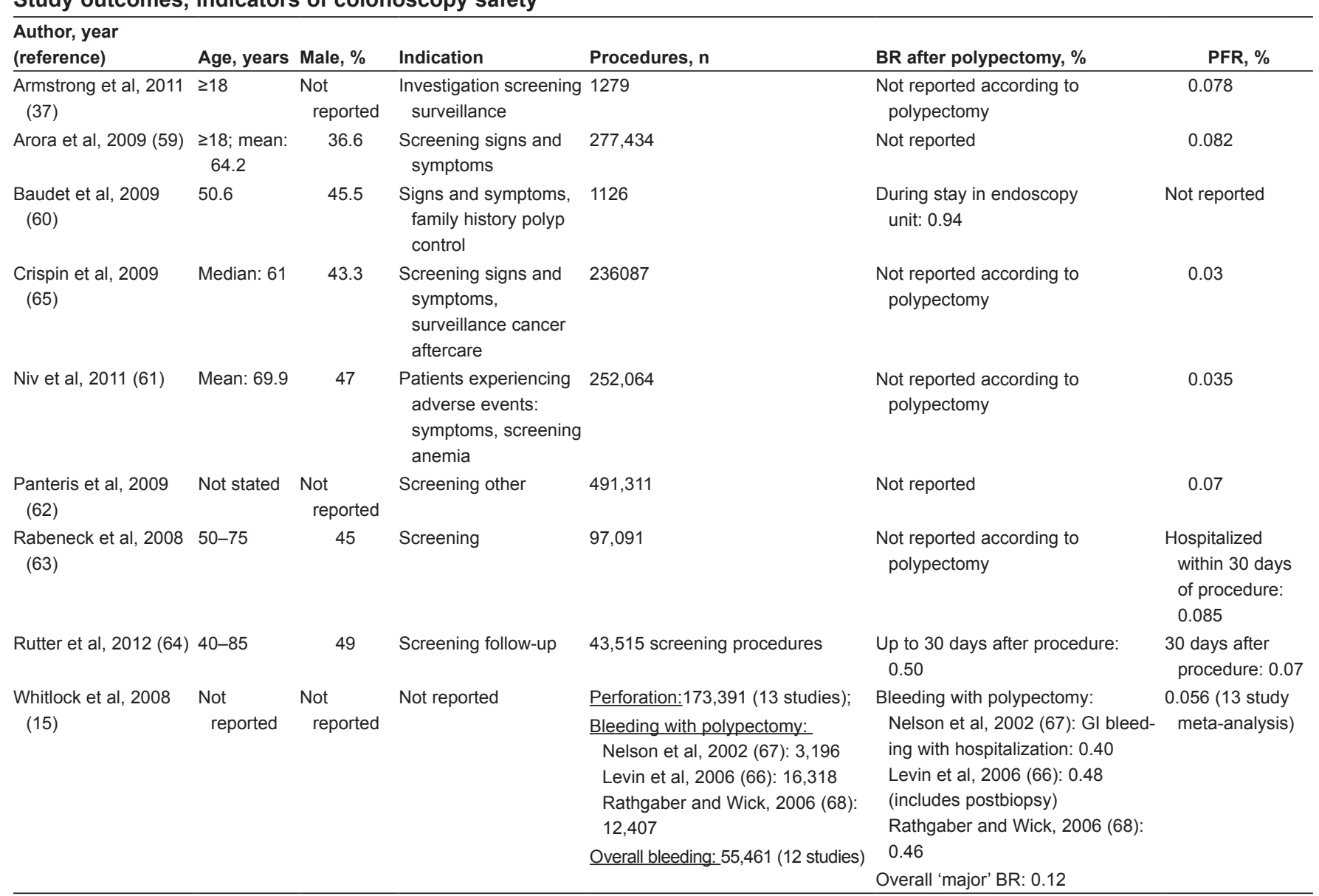

BR Bleeding rate, GI Gastrointestinal; PFR Perforation rate

higher threshold stated in the next Recommendation would apply as endoscopists continue in independent practice.

In determining a threshold for volumes required to attain competency, the working group assessed the relationship between volumes and CIR. In the full-text studies found in the literature, estimates ranged from 275 colonoscopies to achieve an average CIR of $85 \%$, and 400 colonoscopies to achieve an average CIR of $90 \%$ among 41 GI fellows (24), to 500 colonoscopies needed for all fellows in a three-year training program to achieve reliable independent completion rates of at least $90 \%$ (69). The guideline development group chose the moderate value of 300 as a minimum volume to achieve competency because of the variability of the evidence and because lower thresholds defined in the past have, in practice, been shown to be inadequate for most trainees to achieve competence (16). It is preferable to use an objective criterion of technical competence, such as the CIR, rather than volume when granting privileges to physicians for endoscopic procedures (16).

The statement that trainees will remove polyps in at least 50 patients is based on the target of 300 procedures during training. However, it is the opinion of the guideline development group that performing this volume should provide newly trained colonoscopists with sufficient experience with the basic therapeutic techniques in colonoscopy. A similar threshold has been used in other guidelines as a consensusbased recommendation (70).

Qualifying statement:

- Completing recommended training period and meeting volume minimums does not ensure competence in colonoscopy; the achievement of the minimum rate of cecal intubation stated in the Recommendation above is still required as well as proficiency in the cognitive aspects of colonoscopy.
3. Granting, maintenance and renewal of privileges Recommendations:

- Each institution or facility should develop and maintain guidelines for granting and renewing privileges.

- A physician who is requesting privileges to perform colonoscopy after having been away from practice for three or more years, or who has practised endocolonoscopy for less than the equivalent of six months in the previous five years should undergo an individualized educational process before the granting of privileges (71). Detailed training requirements are provided in the College of Physicians and Surgeons of Ontario document,

"Expectations of physicians who have changed or plan to change their scope of practice to include endo-colonoscopy" (71).

- Endoscopists should perform a minimum of 200 colonoscopies per year with a desired minimum CIR for outpatient colonoscopies of $95 \%$ in patients with adequate bowel preparation and no obstructive lesions.

Key evidence: There is good evidence that proficiency in endoscopic procedures is dependent on continued practice and performance of adequate numbers of procedures, although the evidence for precise volume thresholds is controversial (19). One study of volumes and PCCRC diagnosed within six to 36 months of colonoscopy did not find a significant relationship (50). Another study found that endoscopists in the lowest volume quintile (median 63 procedures annually) had threefold higher odds of bleeding or perforation within 30 days of outpatient colonoscopy (OR 2.96 [95\% CI 1.57\% to 5.61\%]) than the highest volume quintile (median 417 procedures annually) (63). The consensus of the guideline development group was that the newer evidence was not significant or consistent enough to warrant a change 
from the recommendation of 200 colonoscopies per year stated in the previous version of the present guideline (7).

\section{INSTITUTIONAL RECOMMENDATIONS}

\section{Patient assessment}

Recommendations: All patients should receive a preprocedure assessment, and any questions that the patient may have should be answered at that time. It is advisable to conduct the preassessment several days before the procedure if it is the patient's first encounter with the endoscopist, to allow sufficient time for safety concerns to be addressed or medication such as warfarin to be withdrawn (8), and to ensure that the patient has sufficient understanding of the bowel preparation process. If a preprocedure assessment with the endoscopist is not available, patient education regarding the issues listed below must be provided in written form and the associated care provider or endoscopy unit staff must be available to answer patient questions. In addition, the referring physician must provide data on medications, allergies and medical conditions listed below to the endoscopist.

Preprocedure patient history and assessment should include:

- instructions for antiplatelet agents/blood thinners, to be individualized to patient risk level; and

- instructions for glucose management in diabetics.

Preprocedure assessment should also include gathering of information regarding:

- indication for colonoscopy;

- a list of current medications and drug allergies;

- ASA classification of patient status and other information that may influence type and level of sedation;

- cardiac and respiratory disorders, including ischemic heart disease, hypertension, sleep apnea, and chronic obstructive pulmonary disease. Cardiorespiratory function should be reviewed on the day of the colonoscopy; and

- any other significant medical problems, including previous abdominal surgery.

Informed consent:

- should be obtained before the administration of sedation; and

- should be documented on the chart.

All patients must receive follow-up care, including:

- reports to the referring and family physician that include the following: type of procedure, date of procedure, sedation received, anatomical extent of colonoscope insertion, colonoscopic findings, histopathology report regarding any tissue that was removed, and recommendations regarding the need for and timing of follow-up colonoscopy as required. Where possible, instructions for arranging follow-up colonoscopy should be provided; and

- a follow-up appointment with the physician who performed the colonoscopy, if indicated.

The recommendations for preprocedure assessment are the consensus of the working group, based on the previous version of the present guideline, and guidance documents published by the EC (8) and the Quality Assurance Task Group of the National CRC Roundtable in US (27).

\section{Infection control}

Recommendations: Administrative aspects:

- Establishment of a comprehensive Quality Assurance and Safety Program and procedures for monitoring adherence to the program, including standard operating procedures for preparing endoscopes and quality assurance procedures for reprocessing endoscopes and their accessories.

- Training and retraining of the staff involved with endoscope care and maintenance of a clear chain of accountability for endoscope processing procedures.
Technical aspects (32):

- Adherence to the endoscope manufacturer's operating manual and instructions for use.

The Expert Panel endorses the standards detailed by the CPSO concerning infection control (26). These standards are summarized below:

- Gastrointestinal endoscopes come into contact with mucous membranes and are considered to be semicritical items. The minimum standard of practice for reprocessing is high-level disinfection.

- Accessories (eg, reusable biopsy forceps) that penetrate mucosal barriers are classified as critical items and must be sterilized between each patient use.

- It is essential that endoscopes are cleaned to remove organic material before disinfection or sterilization.

- Accessories labelled as either single use or disposable should not be reprocessed.

- Endoscopes have been implicated in the transmission of disease when appropriate cleaning or disinfection procedures were not used; therefore, proper cleaning techniques should be used.

- In contrast to the CPSO standards, the Expert Panel recommends that automated endoscope reprocessing (AER), disinfection and sterilization processes, and not manual processes, to be used to protect patients, personnel and equipment.

- Universal precautions must be observed in each facility to prevent contact with blood or other potentially infectious materials. All blood or other potentially infectious material should be considered infectious, regardless of the perceived status of the source individual.

- All personnel performing or assisting with endoscopic procedures should follow universal precautions and wear appropriate equipment to protect themselves from fluid and body substances.

- Eye protection should be worn to prevent contact with splashes during the cleaning procedure and disinfection/sterilization process.

- Moisture- or water-resistant gowns should be worn to prevent contamination of personnel due to splashes of blood or other body fluids or injury due to chemical disinfectant or sterilant contact. Gowns should be changed between patient procedures.

Further guidance from the CPSO, published in 2010, is endorsed (20):

- In endoscopy/colonoscopy units, functionally separate areas are required for reprocessing, scope cabinet and dirty areas.

Key evidence: The recommendations for the administrative and technical aspects of infection control are the consensus of the working group, based on recommendations from the US Food and Drug Administration (32) and the previous PEBC guideline (7).

The remainder of the recommendations, except for the recommendation for AER, are based on guidance provided by the $\operatorname{CPSO}(20,26)$.

The recommendation for automatic endoscope reprocessing was the consensus of the present guideline development group that developed the previous version of this guideline. Since that time, national consensus standards have been released by the ASGE that state: "[Automated Endoscope Reprocessors (AERs)] can enhance efficiency and reliability of high-level disinfection by replacing some manual reprocessing steps...Use of an AER may also reduce exposure of personnel to chemical germicides" (34). Similarly, European Society of Gastrointestinal Endoscopy - European Society of Gastroenterology standards call for the use of automatic "washer-disinfectors" for a number of reasons, including reliable, standardized and validated reprocessing cycles, reduction in the contact of staff and the environment with chemicals, and less risk of damage to scopes (33).

\section{Use of sedation}

Recommendation: There is evidence that adequate sedation contributes to better patient outcomes in terms of greater patient cooperation, 
less patient memory of discomfort, reduction in reported pain and increase in patient tolerance of the procedure. All patients should be offered sedation unless the endoscopist judges this to be contraindicated. Patients need to be aware that they have the right to refuse sedation if they so desire.

Key evidence: The Expert Panel endorses the sedation recommendations contained in the previous version of the present guideline (7).

\section{Monitoring during and after the administration of conscious sedation}

Recommendations:

When conscious or deep sedation is used:

- Patients undergoing procedures with conscious or deep sedation must have continuous monitoring before, during and after sedative administration.

- Monitoring of all patients, including blood pressure, pulse, respiration, level of consciousness, and degree of discomfort at the initiation, during and at the completion of the procedure is recommended. Depending on patient response, assessment may need to be more frequent. These data should be recorded at the endoscopy unit level, using a system chosen by the unit.

- Modern electronic monitoring equipment may facilitate assessment but cannot replace registered nurses or registered practical nurses with appropriate certification or special training in sedation and endoscopy.

- Continuous electrocardiogram monitoring is reasonable in highrisk patients. This subgroup of high-risk patients would include those who have a history of cardiac or pulmonary disease, elderly patients and patients for whom a prolonged procedure is expected.

- The endoscopy unit should have a formal process to document sedation and patient comfort using a system of the unit's choice. The unit should audit its individual physicians' use of sedation.

Key evidence: The Expert Panel endorses the sedation recommendations contained in the previous version of the present guideline (7).

\section{Monitoring during recovery \\ Recommendations:}

- A list of criteria such as the Aldrete score (respiration, oxygen saturation, consciousness, circulation and activity levels) (72) should be used to determine readiness for discharge (73). Readiness for discharge should be documented in the chart.

- Before discharge, preprocedure teaching regarding driving, including the time period for not driving agreed to during the informed consent process, equipment operation, and making decisions requiring judgment should be reinforced. The teaching provided should be in written form and given to the patient before discharge.

- Because the amnesia period that follows the administration of sedation is variable, written instructions should be given to the patient, including the procedures to follow if an emergency arises.

Key evidence: Recommendations regarding monitoring during resuscitation are the consensus of the working group, based on the previous version of the present guideline (7).

\section{Resuscitation capacity}

Recommendation:

- A general plan for resuscitation, including the identification of properly trained personnel should be in place with:

$\circ$ at least one physician certified and current in Advanced Cardiac Life Support on-site and available within $5 \mathrm{~min}$; and

$\circ$ at least one additional person currently certified in Basic Cardiac Life Support in the endoscopy unit or in the room during the procedure (26).

- Resuscitation equipment should be available including defibrillator, endotracheal tubes, airways, laryngoscope, oxygen sources with positive-pressure capabilities, emergency drugs and oxygen tanks.
Key evidence: Recommendations regarding resuscitation capacity are the consensus of the working group, based on the previous version of the present guideline (7).

\section{Endoscope quality}

Recommendations:

- All colonoscopies should be performed using a video colonoscope that can be maintained within manufacturers' specifications.

- The equipment should have the capacity to create photographic records, either paper or digital.

Key evidence: This recommendation is the consensus of the working group.

\section{COLONOSCOPY QUALITY INDICATORS AND AUDITABLE OUTCOMES}

Recommendations where there is sufficient evidence to endorse a specific target in this section are called quality indicators. These include:

- CIR;

- bleeding rate after polypectomy; and

- perforation rate.

Some indicators had insufficient evidence to recommend a specific target; however, the working group agreed that they should be monitored as important components of a quality assurance program. These are labelled auditable outcomes and include:

- ADR;

- PR;

- bowel preparation;

- PCCRC; and

- interval between colonoscopies.

These labels are consistent with those used in other guidance documents $(8,9)$.

\section{CIR}

Cecal intubation is defined as passage of the scope beyond the ileocecal valve into the cecal pole or terminal ileum (9). Lower CIR or completion rate has been significantly associated with greater risk of a PCCRC in a study using a large administrative database in Ontario (50). CIR targets can be unadjusted or reported after adjustment for factors such as indication, poor bowel preparation, strictures, previous colonic surgery (ie, right hemicolectomy) or severe colitis. Adjusted targets are set higher than unadjusted rates.

\section{Recommendation:}

Quality indicator:

- A CIR of $95 \%$ is desirable in patients with adequate bowel preparation and no obstructive lesions.

Key evidence:

- The above $95 \%$ adjusted rate is considered consistent with the $90 \%$ unadjusted rate recommended in the UK in a FOBT-based screening program (9).

- An $85 \%$ to $90 \%$ unadjusted rate for all colonoscopies is recommended by the CAG (14) as a reasonable expectation for "competent colonoscopists".

- Evidence that this expectation may be reasonable in the Canadian context comes from a point-of-care audit, which found that $94.9 \%$ of patients had a complete colonoscopy based on selfreported data from $5 \%$ of practicing Canadian endoscopists (37).

\section{Qualifying statement:}

- Written documentation of colonoscopy completion is required, along with photographic evidence.

- Where data on bowel preparation and colonoscopy findings are not available, use of an unadjusted rate of $90 \%$ is reasonable to audit performance. 


\section{ADR}

Although CIR is the most commonly used quality indicator for colonoscopy, ADR, defined as the proportion of patients that have at least one adenoma identified and removed during colonoscopy, is a more specific and direct indicator of the quality of colonoscopy (42) because adenomas are known cancer precursors. ADR has also been associated with important clinical outcomes such as interval cancers. Expected ADR is influenced by the underlying characteristics of the population, including age, sex and a family history of a first-degree relative with CRC before 60 years of age. ADR can also vary depending on quality of bowel preparation, and the experience level of the endoscopist. Recently, sessile serrated polyps, which are distinct from adenomas, have been recognized as important cancer precursors (74). To date, there is no consensus that they should be measured as a part of the ADR.

\section{Recommendation:}

\section{Auditable outcome:}

An ADR target level is not specified for this indicator; however, it should be tracked and monitored for the following patient subgroups as a key component of the quality assurance program:

- patients undergoing primary screening with colonoscopy;

- patients who have a positive FOBT or FIT; and

- patients with a family history of CRC.

Key evidence: Kaminski et al (49) found ADR to be a reliable independent predictor of the risk of interval CRC. ADRs found in the literature are highly variable, with rates of any adenoma or cancer ranging from 14.9 to $37.5(8,53)$. The wide variation reported likely reflects important differences in the populations studied. As such, these studies are not readily generalizable to the Ontario context. Therefore, the working group determined that there was insufficient evidence to make a specific target recommendation at this time for this indicator. As auditing of this indicator in the Ontario population continues and reporting improves, it is advised that future study be undertaken to determine an appropriate target.

Qualifying statement:

- Endoscopists should monitor their individual ADR.

\section{PR}

$\mathrm{PR}$ is defined as the proportion of patients who have at least one polyp identified and removed during colonoscopy. The previous version of the present guideline did not assess PR as a quality assurance indicator. Since that time, research has been published on the use of PR as a proxy for ADR. This indicator has the advantage that information on the presence or absence of polyps is available at the time of colonoscopy, unlike adenoma detection, which requires pathological confirmation, and that it is captured in health administrative data.

\section{Recommendation:}

\section{Auditable outcome:}

A PR target level is not specified; however, the rate should be tracked and monitored for the following patient subgroups as a key component of the quality assurance program:

- patients undergoing primary screening with colonoscopy;

- patients who have a positive FOBT or FIT; and

- patients with a family history of CRC.

Key evidence: Because this indicator was not used in the previous PEBC guideline, the working group assessed evidence to determine its relationship to previously established quality indicators such as ADR and PCCRC:

- A study found a correlation between ADR and PR of $r=0.88$ (95\% CI $0.78 \%$ to $0.94 \%$ ) in an average-risk asymptomatic population with FOBT-positive test results (36).

- Endoscopists' PRs yielded similar assessments of quality as their ADRs ( $r=0.91, P<0.0001$ in men and $r=0.91, P<0.0001$ in women) in an average-risk screening setting (46). Endoscopists who achieved a PR of $40 \%$ in men and $30 \%$ in women almost always achieved an ADR of $25 \%$ and $15 \%$, respectively, and also found more advanced lesions.
- Baxter et al (54) found that the median PR for endoscopists over a two-year period was $17.7 \%$ (range $0.0 \%$ to $72.5 \%$ ). Patients undergoing colonoscopy performed by an endoscopist with a PR $\geq 25 \%$ were less likely to develop a proximal PCCRC (diagnosed seven to 36 months after the procedure) than if colonoscopy was performed by an endoscopist with a 10\% PR (OR 0.61 [95\% CI $0.42 \%$ to $0.89 \%]$ ). PR was not associated with the diagnosis of a distal PCCRC.

Based on these studies, the working group concluded that PDR is a valid proxy for ADR and may be a useful quality assurance indicator where ADR is not readily available. However, because rates in the literature are highly variable, it is not possible to specify a target for this indicator at the present time. As auditing of this indicator in the Ontario population continues and reporting improves, it may be possible to determine an appropriate target in the future.

\section{Bowel preparation}

Proper bowel preparation is important because it is associated with higher colonoscopy completion rates and ADRs (7). Split dosing (ie, dosing at least one-half of the preparation on the day of the colonoscopy) has been established as superior to dosing all the preparation the day before the test (8), because it enhances the effectiveness of commercial preparations (5).

\section{Recommendation:}

Auditable outcome:

Endoscopists should strive for adequate bowel preparation, and quality of bowel preparation should be recorded and monitored using a standardized scale of the endoscopy unit's choice. Users of the scale should be trained on it use to ensure it is consistently applied.

Key evidence: Several guidelines ([27] and British Society of Gastroenterology) recommend that the percentage of colonoscopies where the bowel preparation was adequate to detect polyps $>5 \mathrm{~mm}$ should be measured, and inadequate preparation should occur in no more than $10 \%$ of colonoscopies (27). As auditing continues, it may be possible to determine an appropriate target for this indicator in the Ontario population in the future.

\section{Qualifying statements:}

- To improve the effectiveness of bowel preparation, where possible, split dosing of the bowel preparation is preferred.

- A standardized tool, such as the OBPS (56) or the Boston Bowel Preparation Scale (57), may be used to assess bowel preparation quality (10). An OBPS score of $<5$ can be used as a cut-off (37).

\section{WT}

WT has been proposed as a proxy quality assurance measure to ensure that endoscopists are taking adequate time to withdraw the endoscope and examine the colon for adenomas.

Recommendation: It is not necessary to achieve a specific WT target or to audit this indicator for quality assurance purposes.

Key evidence and rationale: The previous PEBC guideline found insufficient evidence to set a target for WT, although it was listed as a performance measure. The consensus of the current guideline development group is that WT as an indicator does not necessarily reflect the true characteristics of high-quality endoscopy (75), and that longer procedure time does not necessarily mean higher quality; the endoscopist must be able to recognize important pathological features and have the technical skills to ensure appropriate management (76); therefore, the working group has chosen to focus on other indicators of endoscopic skill. This opinion is supported by a study that did not find a relationship between WT and ADR (44). Capturing WT is less important in a setting where other quality indicators that the working group has recommended for monitoring, including ADR, CIR and complications, can be monitored (55). It is also possible that a focus on WT would have a negative impact on productivity and efficiency for negligible gain (77). 


\section{PCCRC}

This indicator captures the occurrence of new or missed CRC diagnosed after colonoscopy. It is often defined as the proportion of persons with CRC who underwent a colonoscopy within six to 36 months before the diagnosis of CRC (those with a colonoscopy within six months of diagnosis are considered to be detected cancers) (50). The reason for a PCCRC is often unknown, and possible reasons include missed lesions, incomplete removal of adenomas and new, rapidly growing lesions (76). The associated time period in which the PCCRC is diagnosed following the colonoscopy can be specified (eg, one year, three years, five years) (21). Among those with CRC who had colonoscopy, the rates of PCCRC ranged from approximately 5\% (21) to 9\% (50). PCCRC can also be defined as the rate of CRC in a cohort of individuals followed prospectively from the time of colonoscopy until $\mathrm{CRC}$ diagnosis. A Canadian study found that 14 years after negative complete colonoscopy, the overall incidence of CRC was $1.3 \%$ in an Ontario population (78).

Recommendation:

\section{Auditable outcome:}

A target level is not specified for this indicator; however, it should be tracked and monitored as a key component of the quality assurance program.

Key evidence: It is the consensus of the working group that this indicator be added to the list of important quality indicators and monitored at the province-wide level.

Qualifying statement:

- Incidence of PCCRC should be tracked at the facility or at system-wide level, because estimates at the endoscopist level are unstable due to the low incidence of PCCRC.

\section{Bleeding rate after polypectomy}

Bleeding is the most common complication of polypectomy and can occur during or after the procedure (9).

\section{Recommendation:}

\section{Quality indicator:}

Overall rates of clinically significant (leading to hospital admission) postpolypectomy bleeding should be no more than one per 100 colonoscopies.

Key evidence: In the opinion of the working group, bleeding in the absence of polypectomy is not considered to be a clinically significant event; thus, only studies that included patients who had undergone polypectomy during colonoscopy were included in the evidence base for this indicator. Three of 12 studies in the USPSTF meta-analysis met this criterion (15), with rates ranging from $0.40 \%$ (67) to $0.48 \%$ (66). The present systematic review found bleeding after PRs of $0.50 \%$ in the 30 days after the procedure in a screening population (64), and $0.94 \%$ while in the endoscopy unit for a higher risk population (60).

\section{Perforation rate}

Perforation is an uncommon adverse events that that can occur during or shortly after colonoscopy (53). Rates in patients being screened are expected to be lower because these patients are generally healthy and tend not to have colonic conditions that are associated with perforation.

\section{Recommendation:}

Quality indicator:

Overall colonoscopy perforation rates should be $<1$ per 1000 .

\section{Key evidence:}

- Other guidelines have suggested an overall quality threshold of $<1$ per 1000 for perforations caused by colonoscopy $(2,8,14)$.

- A systematic review was conducted by the USPSTF for their clinical practice guideline on screening for CRC (15). In a metaanalysis of 13 studies, it was noted that perforations occurred in asymptomatic populations in 0.56 per 1000 procedures. The majority of perforations were in colonoscopies with polypectomies (although the percentage with polypectomy was only reported in three studies) (15).
- Eight studies located in the present review, which included diagnostic and therapeutic colonoscopies, also found that rates were generally $<1$ per 1000 . For example, using administrative data from Canadian provinces, Rabeneck et al (63) found an outpatient perforation rate in usual clinical practice within 30 days of colonoscopy of 0.85 per 1000 .

\section{Qualifying statements:}

- Colonic conditions that are known to affect the risk of perforation include pseudo-obstruction, ischemia, severe colitis, radiation-induced changes, stricture formation, bulky CRCs, more severe forms of diverticular disease and chronic corticosteroid therapy (53).

- Because perforation is a rare event, perforation rates should be tracked at the facility and/or system-wide level. Measurements at the individual endoscopist level are likely to be unstable.

\section{Interval between colonoscopies}

Although this indicator was not included in the previous PEBC guideline, it has been adopted as an auditable outcome for this version of the guidance document. This indicator addresses the importance of adhering to appropriate evidence-based intervals between colonoscopies, to balance the potential for harm from the rare adverse events associated with colonoscopy, and the benefits of CRC prevention and early detection.

\section{Recommendation:}

\section{Auditable outcome:}

The rate of adherence to locally recommended screening intervals should be monitored at the individual endoscopist level.

Key evidence: There is evidence that many physicians perform examinations at shorter intervals than are recommended, which consumes colonoscopy resources, increases health care costs and exposes patients to unnecessary risk (79). As well, recommended intervals for surveillance for individuals with a family history are often not adhered to, resulting in longer intervals or no follow-up (80). The addition of this indicator and the recommendation to monitor adherence to appropriate intervals between colonoscopies are the opinion of the guideline development group, in keeping with other recent colonoscopy quality assurance guidelines $(8,27)$.

\section{Qualifying statement:}

- The PEBC is currently developing a separate guidance document to be released in 2013 that will provide recommendations on appropriate colonoscopy intervals for individuals at various risk levels.

ACKNOWLEDGEMENTS: The Colonoscopy Quality Assurance Guideline Development Group would like to thank Caitlin Ireland for conducting an audit of the extracted data, and Mark Gichuru for assisting with the data extraction process.

\section{APPENDIX 1: SOURCES INCLUDED IN THE SEARCH FOR EXISTING GUIDELINES}

\section{Databases}

- Inventory of Cancer Guidelines (SAGE): <www.cancerguidelines. ca/Guidelines/inventory/index.php>

- National Guideline Clearing House: <www.guideline.gov/>

- CMAJ Infobase: <www.cma.ca/index.php/ci_id/54316/la_id/1. htm>

International Guideline Developers:

- National Institute for Clinical and Health Excellence

- Scottish Intercollegiate Guidelines Network (UK)

- American Society for Clinical Oncology (US) 
APPENDIX 1: SOURCES INCLUDED IN THE SEARCH FOR EXISTING GUIDELINES - CONTINUED

- National Comprehensive Cancer Network (US) (consensus-based)

- National Health and Medical Research Council (Australia)

- New Zealand Guidelines Group

GI and general surgery associations:

- Canadian Task Force on Preventive Health Care

- College of Physicians and Surgeons of Ontario

- Canadian Association of Gastroenterology

- National Committee on CRC Screening

- American Academy of Family Physicians

- Society of American Gastrointestinal Endoscopic Surgeons

- American Society for Gastrointestinal Endoscopy

- American Society of Colon and Rectal Surgeons

- Joint Advisory Group on Gastrointestinal Endoscopy

- Canadian Society of Gastroenterology Nurses and Associates

- Joint Commission on the Accreditation of Healthcare Organizations (US)

- American Medical Association

Other:

- National Quality Forum

- American Medical Association Physician Consortium for Quality Improvement

- American Gastroenterological Association

- American College of Gastroenterology

- Health Care Facilities Accreditation Program (CA)

- The VA Hospital system

- Society of Gastrointestinal Endoscopic Surgery

- United States Food and Drug Administration

\section{APPENDIX 2: SEARCH TERMS USED IN THE SEARCH} OF ELECTRONIC DATABASES

1. colonoscopy.ti.

2. quality.ti.

3. standards.ti.

4. adverse events.ti.

5. (bleeding or hemorrhage or sedation or training or assessment). ti.

6. bowel preparation.ti.

7. cancer miss rate*.mp.

8. adenoma detection rate*.mp.

9. perforation.ti.

10. withdrawal time.ti.

11. infection control.ti.

12. resuscitation.ti.

13. c?ecal intubation rate.ti.

14. performance measures.ti.

15. competency.ti.

16. polyp detection rate.mp.

17. endoscopy quality.mp.

18. washing.mp. [mp=ti, ab, sh, hw, tn, ot, dm, mf, dv, kw, nm, ps, rs, an, ui]

19. split prep.mp. [mp=ti, ab, sh, hw, tn, ot, dm, mf, dv, kw, nm, ps, rs, an, ui]

20. 2 or 3 or 4 or 5 or 6 or 7 or 8 or 9 or 10 or 11 or 12 or 13 or 14 or 15 or 16 or 17 or 18 or 19

21. 1 and 20

22. limit 21 to english language

23. limit 22 to $y r=" 2006$-Current"

24. children.ti.

25. 23 not 24

26. remove duplicates from 25 
APPENDIX 3

Appraisal of Guidelines for Research and Evaluation 2 (12) assessment of quality assurance guidelines from other jurisdictions*

\begin{tabular}{|c|c|c|c|c|}
\hline Domain & Question & EC & CAG & NHS BCSP \\
\hline \multirow[t]{4}{*}{ Scope and Purpose } & 1. The overall objective(s) of the guideline is (are) specifically described & 7 & 7 & 7 \\
\hline & 2. The health question(s) covered by the guideline is (are) specifically described & 7 & 7 & 7 \\
\hline & $\begin{array}{l}\text { 3. The populations (patients, public, etc) to whom the guideline is meant to apply is } \\
\text { specifically described }\end{array}$ & 7 & 7 & 7 \\
\hline & Total & $21 / 21=100 \%$ & $21 / 21=100 \%$ & $21 / 21=100 \%$ \\
\hline \multirow[t]{3}{*}{ Stakeholder Involvement } & $\begin{array}{l}\text { 1. The views and preferences of the target population (patients, public, etc) have } \\
\text { been sought }\end{array}$ & 4 & 7 & 1 \\
\hline & 2. The target users of the guideline are clearly defined & 7 & 7 & 7 \\
\hline & Total & $11 / 14=79 \%$ & $14 / 14=100 \%$ & $8 / 14=57 \%$ \\
\hline \multirow[t]{9}{*}{ Rigour of Development } & 1. Systematic methods were used to search for evidence & 7 & 7 & 1 \\
\hline & 2. The criteria for selecting the evidence are clearly described & 7 & 7 & 1 \\
\hline & 3. The strengths and limitations of the body of evidence are clearly described & 7 & 7 & 4 \\
\hline & 4. The methods for formulating the recommendations are clearly described & 7 & 7 & 2 \\
\hline & $\begin{array}{l}\text { 6. The health benefits, side effects and risks have been considered in formulating } \\
\text { the recommendations }\end{array}$ & 7 & 7 & 6 \\
\hline & $\begin{array}{l}\text { 7. There is an explicit link between the recommendations and the supporting } \\
\text { evidence }\end{array}$ & 7 & 7 & 7 \\
\hline & 8. The guideline has been externally reviewed by experts prior to its publication & 7 & 5 & 1 \\
\hline & 9. A procedure for updating the guideline is provided & & 1 & 1 \\
\hline & Total & $49 / 49=100 \%$ & $48 / 56=86 \%$ & $23 / 56=41 \%$ \\
\hline \multirow[t]{4}{*}{ Clarity of Presentation } & 1. The recommendations are specific and unambiguous & 7 & 7 & 7 \\
\hline & $\begin{array}{l}\text { 2. The different options for management of the condition or health issue are clearly } \\
\text { presented }\end{array}$ & 7 & 7 & 3 \\
\hline & 3. Key recommendations are easily identifiable & 7 & 7 & 7 \\
\hline & Total & $21 / 21=100 \%$ & $21 / 21=100 \%$ & $17 / 21=81 \%$ \\
\hline \multirow[t]{5}{*}{ Applicability } & 1. The guideline describes facilitators and barriers to its application & 7 & 1 & 4 \\
\hline & $\begin{array}{l}\text { 2. The guideline provides advice and/or tools on how the recommendations can be } \\
\text { put into practice }\end{array}$ & 7 & 3 & 7 \\
\hline & $\begin{array}{l}\text { 3. The potential resource implications of applying the recommendations have been } \\
\text { considered }\end{array}$ & 5 & 2 & 1 \\
\hline & 4. The guideline presents monitoring and/or auditing criteria & 7 & 7 & 7 \\
\hline & Total & $26 / 28=93 \%$ & $13 / 28=46 \%$ & $19 / 28=68 \%$ \\
\hline \multirow[t]{3}{*}{ Editorial Independence } & 1. The views of the funding body have not influenced the content of the guideline & 7 & 2 & 4 \\
\hline & $\begin{array}{l}\text { 2. Competing interests of guideline development group members have been } \\
\text { recorded and addressed }\end{array}$ & 7 & 7 & 1 \\
\hline & Total & $14 / 14=100 \%$ & $9 / 14=64 \%$ & $5 / 14=36 \%$ \\
\hline
\end{tabular}

${ }^{*}$ Ratings are on a scale from 1 (strongly disagree) to 7 (agree). CAG Canadian Association of Gastroenterology; EC European Commission; NHS BCSP National Health Service (United Kingdom) Bowel Cancer Screening Program 


\section{APPENDIX 4}

\section{Guidance located in the targeted search}

\begin{tabular}{|c|c|c|}
\hline Reference, year & Title & Brief description \\
\hline Armstrong et al (10), 2012 & $\begin{array}{l}\text { Canadian Association of Gastroenterology con- } \\
\text { sensus guidelines on safety and quality indi- } \\
\text { cators in endoscopy (2012) }\end{array}$ & $\begin{array}{l}\text { Twenty-three recommendation statements related to ethics, facility standards and } \\
\text { policies, quality assurance, training, education, competency and privileges, } \\
\text { endoscopy reporting standards and patient perceptions }\end{array}$ \\
\hline $\begin{array}{l}\text { Romagnuolo et al, (14), } \\
2008\end{array}$ & $\begin{array}{l}\text { Canadian Credentialling Guidelines in } \\
\text { Colonoscopy }\end{array}$ & $\begin{array}{l}\text { Consensus-based summary of basic requirements for credentialing in colonoscopy } \\
\text { in Canada }\end{array}$ \\
\hline $\begin{array}{l}\text { European Commission (8), } \\
2010\end{array}$ & $\begin{array}{l}\text { European guidelines for quality assurance in } \\
\text { colorectal cancer screening and diagnosis }\end{array}$ & $\begin{array}{l}\text { Standards are provided for quality, safety and patient feedback before and during } \\
\text { the procedure }\end{array}$ \\
\hline $\begin{array}{l}\text { Faigel et al; American } \\
\text { Society for }\end{array}$ & Ensuring Competence in Endoscopy & $\begin{array}{l}\text { A guide to competence and privileging for gastrointestinal endoscopy for hospitals, } \\
\text { credentialling organizations, insurers and health care providers. }\end{array}$ \\
\hline
\end{tabular}

Gastrointestinal

Endoscopy (16), 2007

Conjoint Committee* (no Conjoint Committee for the Recognition of date) (18)

Training in Gastrointestinal Endoscopy. Information for Registrants

Dominitz et al (19), 2008 Renewal of and proctoring for endoscopic privileges (ASGE 2008)

Lieberman et al (27), 2007 Standardized colonoscopy reporting and data system: report of the Quality Assurance Task Group of the National Colorectal Cancer Roundtable

National Bowel Cancer Screening Program Quality Working Group (2), 2009

Society of Gastrointestinal and Endoscopic

Granting of Privileges for Gastrointestinal Endoscopy

Surgeons (82), 2010,

USA
Improving Colonoscopy Services in Australia

Training requirements for certification in endoscopy, including colonoscopy

A guideline for renewal of and proctoring for endoscopic privileges

An outline for a standardized colonoscopy reporting and data system. To develop this document, the Quality Assurance Task Group of the National Colorectal Cancer Roundtable used the quality indicators recommended by the Multi-Society Task Force on Colorectal Cancer (53). Includes some quality cut-offs that have appeared previously in the literature. Continuous quality improvement targets are provided for: pre-endoscopy examination: patient demographics and history $(n=3)$, assessment of patient risk and comorbidity $(n=1)$, procedure indications $(n=5)$, procedure: technical indications $(n=5)$, colonoscopic findings $(n=2)$, assessment of procedure results (see pathology), interventions/unplanned events $(n=3)$, follow-up plan $(n=1)$ and pathology $(n=1)$

Proposes policy development in four streams: 1 . The colonoscopy procedure, 2 Colonoscopy facilities and equipment, 3. Documentation and reported, and 4. Skills, training, certification and credentialing. Standards are provided for the preprocedure phase (assessment of patient indications and risk, patient consent, quality of bowel preparation) and the procedure phase (proficiency of proceduralist and minimization of complications)

Another consensus-based guideline notes that improving the overall impact of screening colonoscopy requires a programmatic approach that addresses quality issues at several levels.

The recommended quality indicators include:

- Cecal intubation rates

- Withdrawal time

- Adenoma detection rates

- Appropriate intervals between endoscopic studies based on family and persona history and number and histological type of polyps on last colonoscopy

- Minor and major complication rates

- Preprocedure medical evaluation

- Appropriate preparation instructions

National Health Service Bowel Cancer Screening Program (9), 2011

Joint Advisory Group on GI BSG Quality and Safety Indicators for Endoscopy - British Endoscopy

Society of

Gastroenterology (BSG), (51), 2007

Whitlock et al (15), 2008
Quality Assurance Guidelines for Colonoscopy

\section{Quali} and attendance, consent, sedation, cecal intubation rates, neoplasia detection, withdarawal time, polyp recovery and harms including perforation, bleeding and other adverse events

The BSG Endoscopy Committee developed indicators, which underpin the respective indicators of the GRS. Specifically, quality indicators are provided for colonoscopy and flexible sigmoidoscopy, but the guideline may be superceded by the NHS Quality Assurance Guidelines for Colonoscopy

Clinical practice guideline with relevant information and meta-analysis on complication rates
Screening for colorectal cancer: A targeted, updated systematic review for the U.S.

Preventive Services Task Force

${ }^{*}$ Royal Australasian College of Surgeons, Gastroenterological Society of Australia, The Royal Australian College of Physicians and Surgeons. GRS Global Rating Scale; NHS National Health Service 


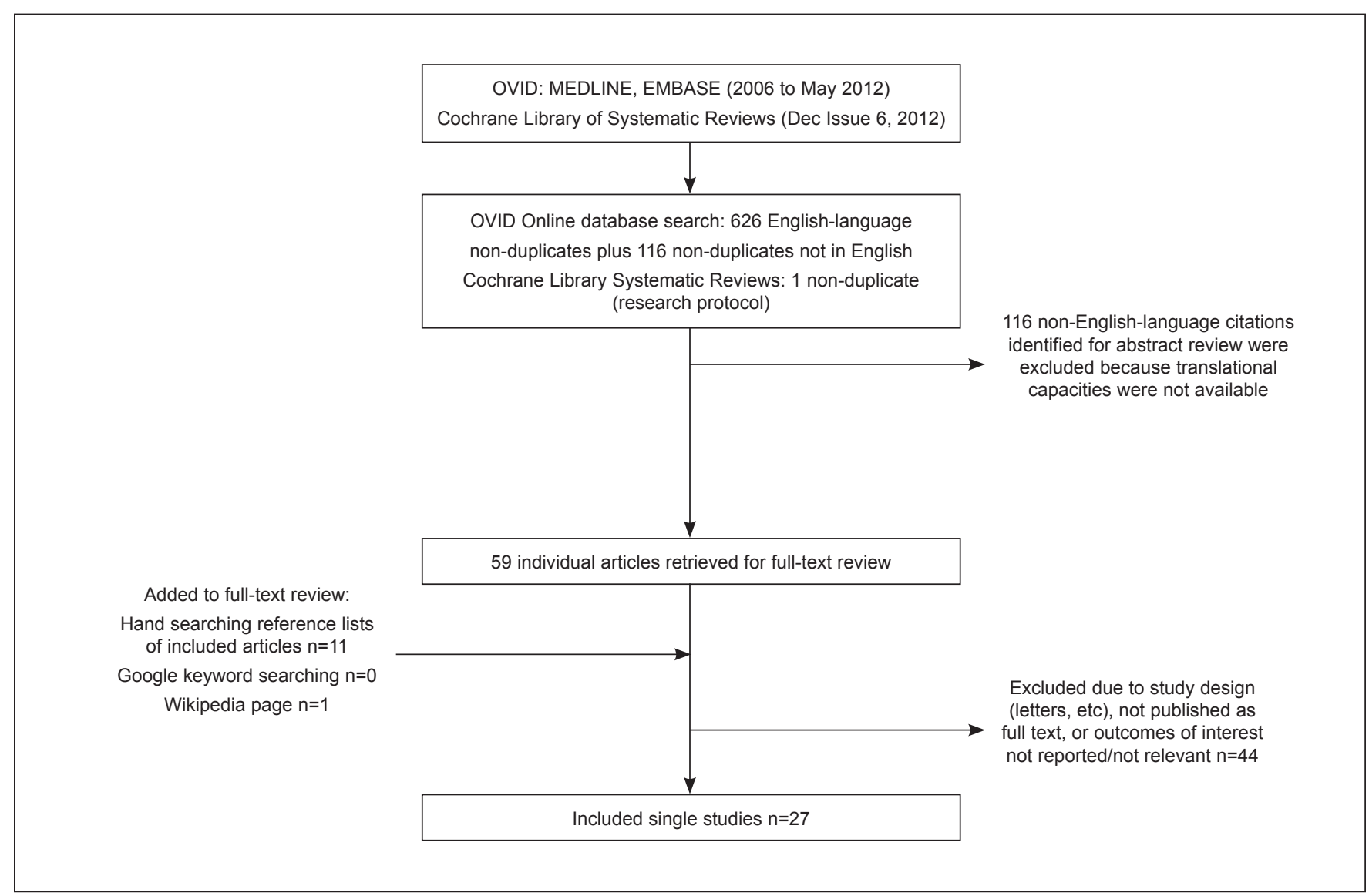

Appendix 5) Literature search results flow diagram 


\section{REFERENCES}

1. Canadian Cancer Society's Steering Committee on Cancer Statistics. Canadian Cancer Statistics 2011. Toronto: Canadian Cancer Society, 2011.

2. National Bowel Cancer Screening Program Quality Working Group. Improving Colonoscopy Services in Australia. 2009.

3. World Cancer Research Fund/American Institute for Cancer Research. Food N, Physical Activity, and the Prevention of Cancer: a Global Perspective. Washington, DC: AICR, 2007.

4. Garcia J BJ, Uetrecht C, Kennedy E, et al. Healthy eating, physical activity, and healthy weights guideline for public health in Ontario. Toronto: Cancer Care Ontario; 2010 March 7. Program in Evidence-Based Care Report No. 23-1.

5. Rex DK, Johnson DA, Anderson JC, Schoenfeld PS, Burke CA, Inadomi JM. American College of Gastroenterology guidelines for colorectal cancer screening 2008. Am J Gastroenterol 2009; 104:739-50.

6. National Comprehensive Cancer Network. Colorectal Cancer Guidelines, 2012. <www.nccn.org> (Accessed June 6, 2012).

7. Rabeneck L, Rumble RB, Axler J, et al. Cancer Care Ontario Colonoscopy Standards. Toronto: Cancer Care Ontario; 2007 October 7. Program in Evidence-Based Care Evidence-Based Series No.:15-5.

8. European Commission. European guidelines for quality assurance in colorectal cancer screening and diagnosis, 2010. Belgium: European Comission.

9. National Health Service Bowel Cancer Screening Program. Quality Assurance Guidelines for Colonoscopy. 2011.

10. Armstrong D, Barkun A, Bridges R, et al. Canadian Association of Gastroenterology consensus guidelines on safety and quality indicators in endoscopy. Can J Gastroenterol 2012;26:17-31.

11. Browman GP, Levine MN, Mohide EA, et al. The practice guidelines development cycle: A conceptual tool for practice guidelines development and implementation. J Clin Oncol 1995;13:502-12.

12. Brouwers M, Kho ME, Browman GP, et al. AGREE II: Advancing guideline development, reporting and evaluation in healthcare. CMAJ 2010. Epub 2010 Jul 5

13. AGREE Collaboration. Development and validation of an international appraisal instrument for assessing the quality of clinical practice guidelines: the AGREE project. Qual Safe Health Care 2003;12:18-23.

14. Romagnuolo J, Enns R, Ponich T, Springer J, Armstrong D, Barkun AN. Canadian credentialing guidelines for colonoscopy. Can J Gastroenterol 2008;22:17-22.

15. Whitlock EP, Lin JS, Liles E, Beil TL, Fu R. Screening for colorectal cancer: A targeted, updated systematic review for the U.S. Preventive Services Task Force. Ann Intern Med 2008 4;149:638-58.

16. Faigel DO, Baron TH, Lewis B, et al. Ensuring competence in endoscopy. ASGE Press; 2006. <www.asge.org/WorkArea/ showcontent.aspx?id=3384> (Accessed June 8, 2012).

17. Armstrong D, Enns R, Ponich T, Romagnuolo J, Springer J, Barkun AN. Canadian credentialing guidelines for endoscopic privileges: An overview. Can J Gastroenterol 2007;21:797-801.

18. Conjoint Committee for the Recognition of Training in Gastrointestinal Endoscopy. Information for Registrants. $<$ http://conjoint.gesa.org.au/information.html\#training $>$ (Accessed June 11, 2012).

19. Dominitz JA, Ikenberry SO, Anderson MA, et al. Renewal of and proctoring for endoscopic privileges. Gastrointest Endosc 2008;67:10-6.

20. College of Physicians and Surgeons of Ontario. Guide to Applying the Out-of-Hospital Standards in Endoscopy/Colonoscopy Premises. November 2011.

21. Rabeneck L, Paszat LF. Circumstances in which colonoscopy misses cancer. Frontline Gastroenterol 2010;1:52-8.

22. Tinmouth JM, Przybysz R, Lewis N, Rabeneck L. Population-based measurement of colonoscopy quality in Ontario's colorectal cancer screening program, Colon Cancer Check. Gastrointest Endosc 2011;1:AB433.

23. Lee SH, Chung IK, Kim SJ, et al. An adequate level of training for technical competence in screening and diagnostic colonoscopy: A prospective multicenter evaluation of the learning curve. Gastrointest Endosc 2008;67:683-9.

24. Sedlack RE. Training to competency in colonoscopy: Assessing and defining competency standards. Gastrointest Endosc 2011;74:355-66 (Erratum in 2011;74:729).
25. Spier BJ, Durkin ET, Walker AJ, Foley E, Gaumnitz EA, Pfau PR. Surgical resident's training in colonoscopy: Numbers, competency, and perceptions. Surg Endosc Other Intervent Tech 2010;24:2556-61.

26. College of Physicians and Surgeons of Ontario. Independent Health Facilities Clinical Practice Parameters and Facility Standards for Endoscopy. 2006. Toronto: College of Physicians and Surgeons of Ontario.

27. Lieberman D, Nadel M, Smith RA, et al. Standardized colonoscopy reporting and data system: Report of the Quality Assurance Task Group of the National Colorectal Cancer Roundtable. Gastrointest Endosc 2007;65:757-66.

28. Cancer Council Australia. Clinical Practice Guidelines for Surveillance Colonoscopy, 2011. Sydney: Cancer Council Australia.

29. McQuaid KR, Laine L. A systematic review and meta-analysis of randomized, controlled trials of moderate sedation for routine endoscopic procedures. Gastrointest Endosc 2008;67:910-23.

30. Rex DK, Bond JH, Winawer S, et al. Quality in the technical performance of colonoscopy and the continuous quality improvement process for colonoscopy: Recommendations of the U.S. Multi-Society Task Force on Colorectal Cancer. Am J Gastroenterol 2002;97:1296-308.

31. Faigel DO, Pike IM, Baron TH, et al. Quality indicators for gastrointestinal endoscopic procedures: an introduction. Am J Gastroenterol 2006;101:866-72.

32. U.S. Food and Drug Administration and Centers for Disease Control and Prevention and Department of Veterans Affairs, Preventing Cross-Contamination in Endoscope Processing. 2009. $<$ www.fda.gov/MedicalDevices/Safety/AlertsandNotices/ucm190273. htm?utm_campaign=Google2\&utm_source=fdaSearch\&utm medium $=$ website $\&$ utm_term $=$ endoscope $\& u t m \_$content $=1>$ (Accessed June 26, 2102).

33. Beilenhoff U, Neumann CS, Rey JF, et al. ESGE-ESGENA Guideline: Cleaning and disinfection in gastrointestinal endoscopy. Endoscopy 2008;40:939-57.

34. American Society of Gastrointestinal Endoscopists. Automated endoscope reprocessors. Gastrointest Endosc 2009;69:771-6.

35. Valori R, Sint Nicolaas J, de Jonge V. Quality assurance of endoscopy in colorectal cancer screening. Best Pract Res Clin Gastroenterol 2010;24:451-64.

36. Denis B, Sauleau EA, Gendre I, Piette C, Bretagne JF, Perrin P. Measurement of adenoma detection and discrimination during colonoscopy in routine practice: An exploratory study. Gastrointest Endosc 2011;74:1325-36.

37. Armstrong D, Hollingworth R, Macintosh D, et al. Point-of-care, peer-comparator colonoscopy practice audit: The Canadian Association of Gastroenterology Quality Program - Endoscopy. Can J Gastroenterol 2011;25:13-20.

38. Barclay RL, Vicari JJ, Greenlaw RL. Effect of a time-dependent colonoscopic withdrawal protocol on adenoma detection during screening colonoscopy. Clin Gastroenterol Hepatol 2008;6:1091-8.

39. Gellad ZF, Weiss DG, Ahnen DJ, Lieberman DA, Jackson GL, Provenzale D. Colonoscopy withdrawal time and risk of neoplasia at 5 years: Results from VA cooperative studies program 380 . Am J Gastroenterol 2010;105:1746-52.

40. Goncalves AR, Ferreira C, Marques A, Ribeiro LC, Velosa J. Assessment of quality in screening colonoscopy for colorectal cancer. Clin Exp Gastroenterol 2011;4:277-81.

41. Hsieh YH, Tseng KC, Chou AL. Targeting withdrawal time to 6 minutes can increase polyp detection during colonoscopy. Tzu Chi Med J 2009;21:222-6.

42. Millan MS, Gross P, Manilich E, Church JM. Adenoma detection rate: The real indicator of quality in colonoscopy. Dis Colon Rectum 2008;51:1217-20.

43. Overholt BF, Brooks-Belli L, Grace M, et al. Withdrawal times and associated factors in colonoscopy: A quality assurance multicenter assessment. J Clin Gastroenteol 2010;44:e80-e6.

44. Sawhney MS, Cury MS, Neeman N, et al. Effect of institution-wide policy of colonoscopy withdrawal time $>=7$ minutes on polyp detection. Gastroenterology 2008;135:1892-8.

45. Simmons DT, Harewood GC, Baron TH, et al. Impact of endoscopist withdrawal speed on polyp yield: Implications for optimal colonoscopy withdrawal time. Aliment Pharmacol Ther 2006;24:965-71.

46. Williams JE, Holub JL, Faigel DO. Polypectomy rate is a valid quality measure for colonoscopy: Results from a national endoscopy database. Gastrointest Endosc 2012;75:576-82. 
47. Williams JE, Le TD, Faigel DO. Polypectomy rate as a quality measure for colonoscopy. Gastrointest Endosc 2011;73:498-506.

48. Lee RH, Tang RS, Muthusamy VR, et al. Quality of colonoscopy withdrawal technique and variability in adenoma detection rates (with videos). Gastrointest Endosc 2011;74:128-34.

49. Kaminski MF, Regula J, Kraszewska E, et al. Quality indicators for colonoscopy and the risk of interval cancer. N Engl J Med 2010;362:1795-803.

50. Baxter NN, Sutradhar R, Forbes SS, Paszat LF, Saskin R, Rabeneck L. Analysis of administrative data finds endoscopist quality measures associated with postcolonoscopy colorectal cancer. Gastroenterology 2011;140:65-72.

51. Joint Advisory Group on GI Endoscopy. BSG quality and safety indicators for endoscopy, 2007. <www.thejag.org.uk> (Accessed June 15, 2012).

52. Williams JE, Domi Le T, Faigel DO. Polypectomy rate as a surrogate marker for adenoma detection in quality measurement for colonoscopy. Gastrointest Endosc 2010;71:AB146.

53. Rex DK, Petrini JL, Baron TH, et al. Quality indicators for colonoscopy. Am J Gastroenterol 2006;101:873-85.

54. Baxter NN, Sutradhar R, Forbes S, Paszat L, Saskin R, Rabeneck L. Can quality indicators for colonoscopy be derived from administrative data? Identifying predictors of new or missed cancers after colonoscopy. Gastrointest Endosc 2009;69:AB120.

55. Yarze JC. Utility of colonoscopy withdrawal time measurement in the setting of an adequate adenoma detection rate. Gastrointest Endosc 2011;73:189.

56. Rostom A, Jolicoeur E. Validation of a new scale for the assessment of bowel preparation quality. Gastrointest Endosc 2004;59:482-6.

57. Lai EJ, Calderwood AH, Doros G, Fix OK, Jacobson BC. The Boston Bowel Preparation Scale: A valid and reliable instrument for colonoscopy-oriented research. Gastrointest Endosc 2009;69 (3 Suppl):620-5.

58. Bressler B, Paszat LF, Chen Z, Rothwell DM, Vinden C, Rabeneck L. Rates of new or missed colorectal cancers after colonoscopy and their risk factors: A population-based analysis. Gastroenterology 2007;132:96-102.

59. Arora G, Mannalithara A, Singh G, Gerson LB, Triadafilopoulos G. Risk of perforation from a colonoscopy in adults: A large population-based study. Gastrointest Endosc 2009;69(3 Suppl):654-64.

60. Baudet JS, Diaz-Bethencourt D, Aviles J, Aguirre-Jaime A. Minor adverse events of colonoscopy on ambulatory patients: The impact of moderate sedation. Eur J Gastroenterol Hepatol 2009;21:656-61.

61. Niv Y, Gershtansky Y, Kenett RS, Tal Y, Birkenfeld S. Complications in colonoscopy: Analysis of 7-year physician-reported adverse events. Eur J Gastroenterol Hepatol 2011;23:492-8.

62. Panteris V, Haringsma J, Kuipers EJ. Colonoscopy perforation rate, mechanisms and outcome: From diagnostic to therapeutic colonoscopy. Endoscopy 2009;41:941-51.

63. Rabeneck L, Paszat LF, Hilsden RJ, et al. Bleeding and perforation after outpatient colonoscopy and their risk factors in usual clinical practice. Gastroenterology 2008;135:1899-906.e1.

64. Rutter CM, Johnson E, Miglioretti DL, Mandelson MT, Inadomi J, Buist DS. Adverse events after screening and follow-up colonoscopy. Cancer Causes Control 2012;23:289-96.
65. Crispin A, Birkner B, Munte A, Nusko G, Mansmann U. Process quality and incidence of acute complications in a series of more than 230,000 outpatient colonoscopies. Endoscopy 2009;41:1018-25.

66. Levin TR, Zhao W, Conell C, et al. Complications of colonoscopy in an integrated health care delivery system. Ann Intern Med 2006;145:880-6.

67. Nelson DB, McQuaid KR, Bond JH, Lieberman DA, Weiss DG, Johnston TK. Procedural success and complications of large-scale screening colonoscopy. Gastrointest Endosc 2002;55:307-14.

68. Rathgaber SW, Wick TM. Colonoscopy completion and complication rates in a community gastroenterology practice. Gastrointest Endosc 2006;64:556-62.

69. Spier BJ, Benson M, Pfau PR, Nelligan G, Lucey MR, Gaumnitz EA. Colonoscopy training in gastroenterology fellowships: Determining competence. Gastrointest Endosc 2010;71:319-24.

70. MacKen E, Moreels T, Vannoote J, Siersema PD, Van Cutsem E. Quality assurance in colonoscopy for colorectal cancer diagnosis. Eur J Surg Oncol 2011;37:10-5.

71. College of Physicians and Surgeons of Ontario. Expectations of physicians who have changed or plan to change their scope of practice to include endo-colonoscopy. Toronto: College of Physicians and Surgeons of Ontario.

72. Aldrete JA. The post-anesthesia recovery score revisited. J Clin Anesth 1995;7:89-91.

73. Armstrong D, Hollingworth R, Macintosh DG, et al. Quality indicators for colonoscopy in Canada: The Canadian Association of Gastroenterology (CAG) endoscopy quality initiative (EQI) practice audit project. Gastroenterology 2009;1:A332.

74. Sheridan TB, Fenton H, Lewin MR, et al. Sessile serrated adenomas with low- and high-grade dysplasia and early carcinomas: An immunohistochemical study of serrated lesions "Caught in the Act". Am J Clin Pathol 2006;126:564-71.

75. Inadomi JM. In search of quality colonoscopy. Gastroenterology 2008;135:1845-7.

76. Lieberman D. A call to action - measuring the quality of colonoscopy. N Engl J Med 2006;355:2588-9.

77. Lin OS. From good to great: Further thoughts on improving quality during routine colonoscopy. Gastrointest Endosc 2011;73:464-6.

78. Lakoff J, Paszat LF, Saskin R, Rabeneck L. Risk of developing proximal versus distal colorectal cancer after a negative colonoscopy: A population-based study. Clin Gastroenterol Hepatol 2008;6:1117-21; quiz 064.

79. Krist AH, Jones RM, Woolf SH, et al. Timing of repeat colonoscopy: Disparity between guidelines and endoscopists' recommendation. Am J Prev Med 2007;33:471-8.

80. Carey M, Sanson-Fisher R, Macrae F, et al. Improving adherence to surveillance and screening recommendations for people with colorectal cancer and their first degree relatives: A randomized controlled trial. BMC Cancer 2012;12:62.

81. College of Physicians and Surgeons of Ontario. Out-of-Hospital Premises Standards. September, 2010. Toronto: College of Physicians and Surgeons of Ontario.

82. Society of American Gastrointestinal and Endoscopic Surgeons. Granting Privileges for Gastrointestinal Endoscopy. SAGES publication No. 0011. Los Angeles: Society of American Gastrointestinal Endoscopic Surgeons; revised 2010. 


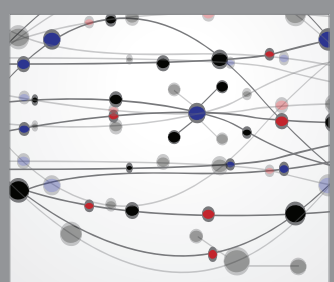

The Scientific World Journal
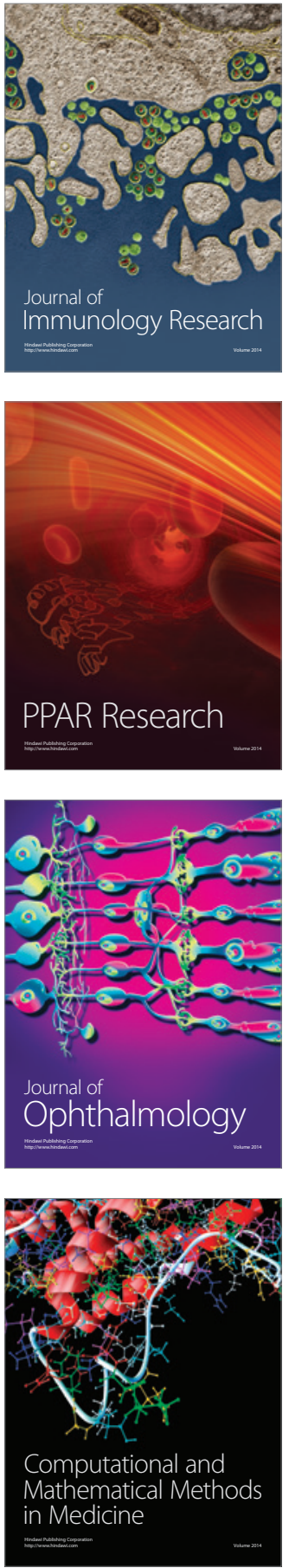

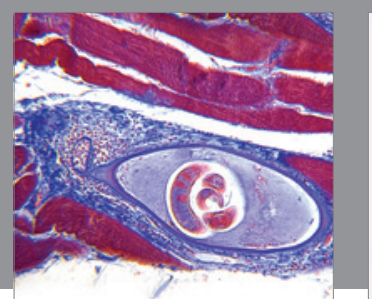

Gastroenterology Research and Practice

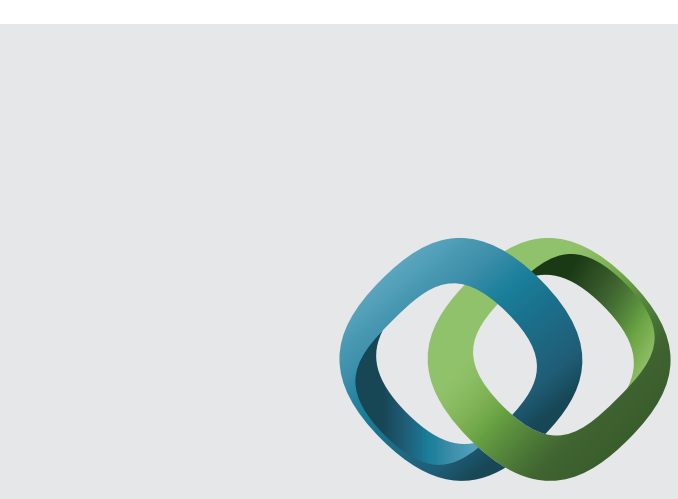

\section{Hindawi}

Submit your manuscripts at

http://www.hindawi.com
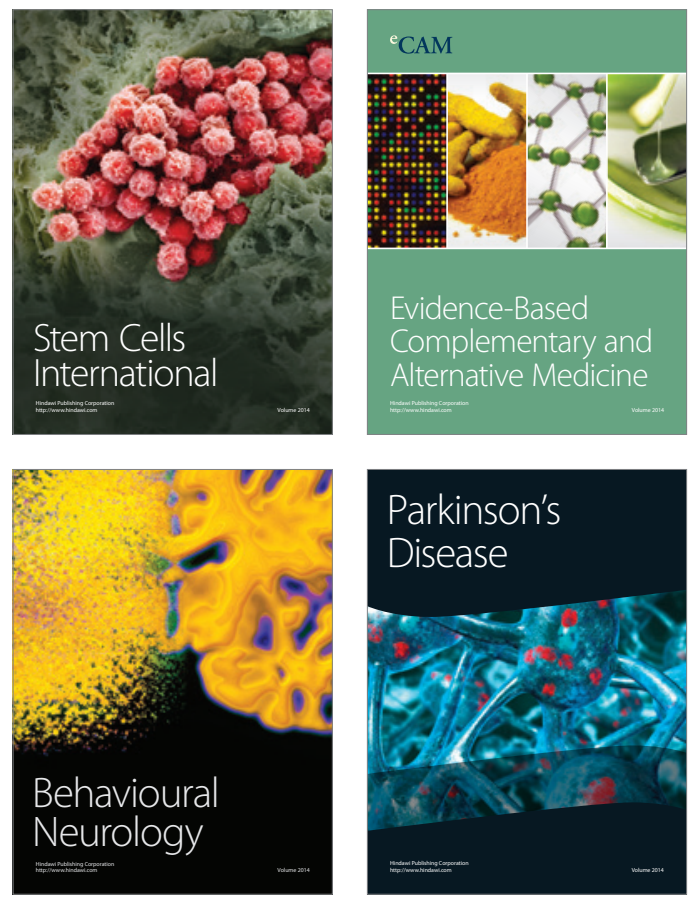
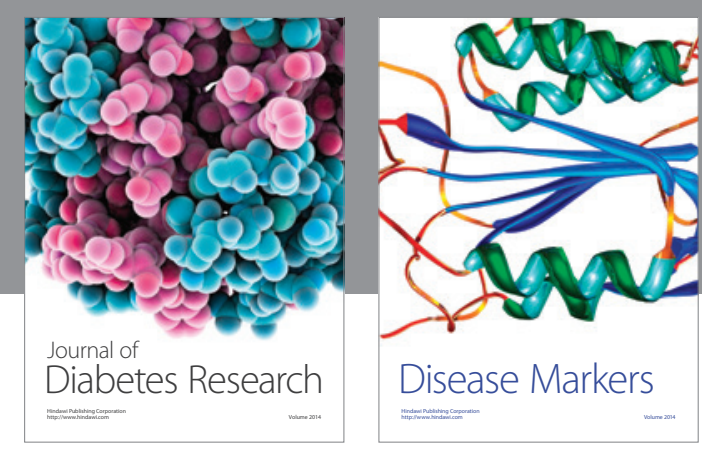

Disease Markers
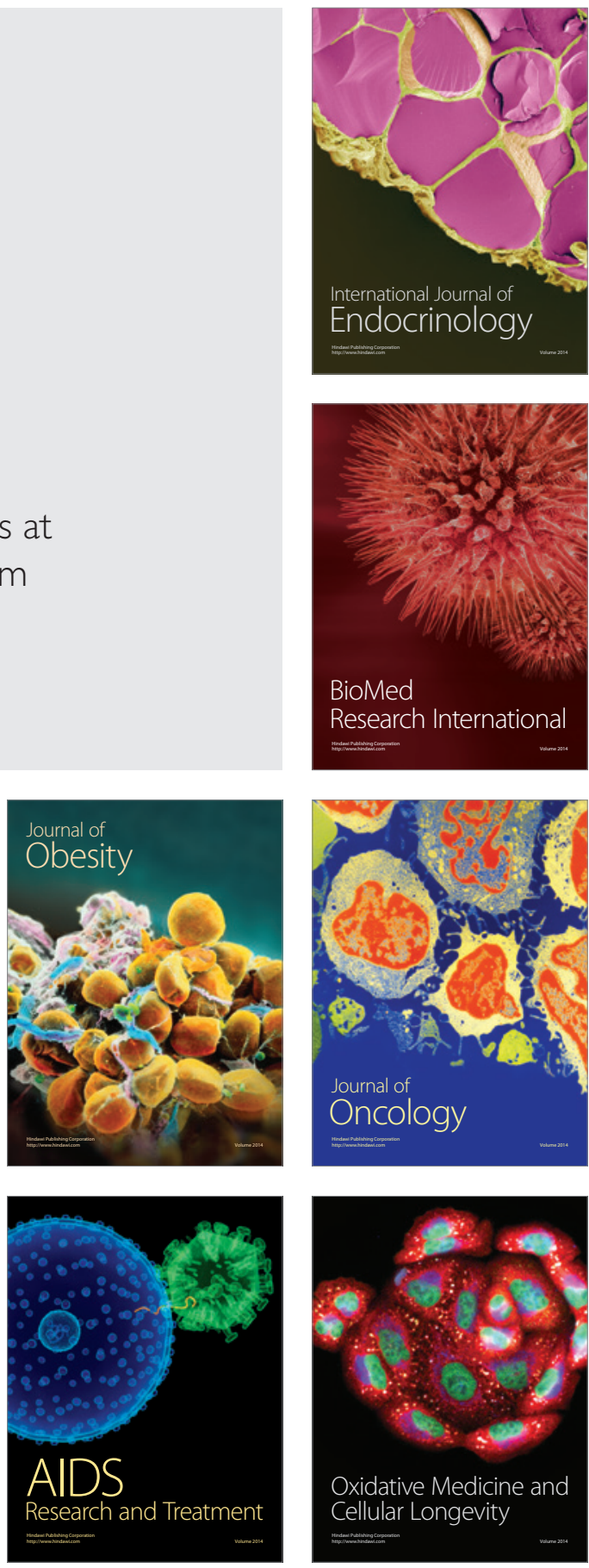